\title{
Thermodynamics of the Reduction Roasting of Nickeliferous Laterite Ores
}

\author{
R. Elliott, C. A. Pickles*, J. Forster \\ Robert M. Buchan Department of Mining, Queen's University, Kingston, Canada \\ Email: ^christopher.pickles@queensu.ca
}

How to cite this paper: Elliott, R., Pickles, C.A. and Forster, J. (2016) Thermodynamics of the Reduction Roasting of Nickeliferous Laterite Ores. Journal of Minerals and Materials Characterization and Engineering, 4, 320-346.

http://dx.doi.org/10.4236/jmmce.2016.46028

Received: September 10, 2016

Accepted: November 1, 2016

Published: November 4, 2016

Copyright $\odot 2016$ by authors and Scientific Research Publishing Inc. This work is licensed under the Creative Commons Attribution International License (CC BY 4.0).

http://creativecommons.org/licenses/by/4.0/

\begin{abstract}
The global nickel sulphide resources are becoming more difficult to mine and, as a result, there is increasing interest in the current and future development of the oxidic nickel laterite deposits. In comparison to the sulphide ores, the nickel laterites cannot be readily upgraded by conventional means and growing attention is being focused on the development of new methods for processing these ores. In this paper, firstly, brief overviews of laterite ore mineralogy and the conventional techniques used to extract the nickel from both the limonitic and the saprolitic nickeliferous laterites are provided. Secondly, previous research on the thermodynamic modelling of the reduction of the laterites is discussed. Thirdly, an improved thermodynamic model is used to predict the equilibrium products arising from the solid state reduction of both the limonitic and the saprolitic ores. Based on these thermodynamic predictions, the reduction behaviors of the two ore types are compared in terms of nickel recovery and grade in the ferronickel product. The effects of reduction temperature, ore composition and carbon additions were studied. Finally, the results from the simulations are compared to the experimental data available in the literature.
\end{abstract}

\section{Keywords}

Limonite, Saprolite, Nickel, Thermodynamics, Reduction

\section{Introduction}

Metallic nickel is primarily obtained from two ore types: nickel sulphide and nickeliferous laterite (oxide) ores. Global nickel resources averaging a minimum nickel grade of about $1 \%$ contain about 130 million tons of nickel, and the distribution between the nickel sulphides and nickel laterites is estimated to be approximately $40 \%$ and $60 \%$, respectively [1]. Nickeliferous laterite ores may be divided into two types: limonite and 
saprolite. The limonitic ore occurs as the upper layer of the laterite deposit and is primarily composed of goethite, (FeO-OH). This layer typically has $0.5 \%$ to $1.7 \%$ nickel, $40 \%$ to $60 \%$ iron and low silica ( $>20 \%)$ and magnesia (>10\%) contents [2]. The saprolitic ore occurs as a layer below the limonite, separated by an intermediate layer of smectite clay. This lower layer is characterized by higher nickel grades ( $1.5 \%$ to $3 \%)$, lower iron contents $(<30 \%)$ and significantly higher magnesium silicate contents. In the limonite, the nickel substitutes for iron in the iron hydroxide crystal lattice $((\mathrm{Fe}, \mathrm{Ni}) \mathrm{O} \cdot \mathrm{OH})$, while in the saprolite, both nickel and iron substitute for magnesium as part of the various magnesium silicate minerals, such as garnierite, $\left(\mathrm{Mg}, \mathrm{Fe}, \mathrm{Ni}_{3} \mathrm{Si}_{2} \mathrm{O}_{5}(\mathrm{OH})_{4}[3]\right.$.

In the nickel sulphide ores, nickel occurs as the discrete mineral pentlandite ( $(\mathrm{Fe}$, $\mathrm{Ni})_{9} \mathrm{~S}_{8}$ ), which can be readily liberated by physical separation methods and concentrated using flotation techniques. This ability to be concentrated by conventional beneficiation methods yields a significant costs savings, resulting in a high grade nickel concentrate, which can be smelted to produce a saleable product. Conversely, the laterite ores are not amenable to conventional beneficiation techniques [4], since the nickel is in the crystal structure. Therefore, chemical separation is required before the nickel can be recovered. Typically, the limonitic ores are processed by hydrometallurgical techniques, while the saprolitic ores are treated by pyrometallurgical processes. The hydrometallurgical processes consume excessive amounts of acid, while pyrometallurgical nickel extraction requires high temperatures, analogous to those employed in the smelting of the nickel sulphide ores. However, since the nickel in the laterites cannot be concentrated to any significant degree, then the volume of material to be processed is much larger than for the sulphide ores. These factors result in laterite treatment methods which are both energy intensive and costly. Therefore, it is of particular interest to develop a lower cost alternative for processing these ores.

One possible processing route would be the production of a concentrate from the nickeliferous laterites, by solid state reduction followed by physical separation of the ferronickel. This is an attractive alternative to the current hydrometallurgical and pyrometallurgical methods of processing laterite ores. The fundamentals of this method have previously been discussed in detail [5] [6]. The objective of the current work was to apply thermodynamic models to the reduction roasting of both a limonitic ore and a saprolitic ore and also to determine the optimum reduction conditions, using carbon as the reducing agent. Additionally, the two ore types are compared in terms of their reduction behavior and also the simulations of the thermodynamic model are compared to the currently available experimental results.

\section{Prior Thermodynamic Reduction Studies}

Several authors have previously modelled the reduction of the nickeliferous laterite ores and examined the effect of various reduction conditions on the nickel grades and recoveries [7]-[15]. These prior thermodynamic studies and their shortcomings have been critically reviewed in depth [14] [16] and therefore only the main points of relevance to the present work are discussed here. In general, these studies considered the reduction 
of a limonitic ore by mixed reducing atmospheres of $\mathrm{CO}, \mathrm{CO}_{2}, \mathrm{H}_{2}$, and/or $\mathrm{H}_{2} \mathrm{O}$ across a range of temperatures, and reported the effect of varying these conditions on the achieved nickel recoveries and grades in the ferronickel phase. Generally, ideal behavior of the condensed species was assumed. In all cases it was reported that the nickel grades and recoveries were strongly dependent on the reducing atmosphere employed. More oxidizing atmospheres (e.g. a higher ratio of $\mathrm{CO}_{2}$ to $\mathrm{CO}$ ) improved selectivity, yielding higher nickel grades at the cost of reduced nickel recoveries to the ferronickel phase. This decreased nickel recovery is due to the formation of nickel oxide under more oxidizing conditions, and its subsequent dissolution in the wüstite $(\mathrm{FeO})$ phase. These studies also recommended that the amount of reductant used be equal to or less than the stoichiometric requirement in order to achieve the greatest selectivity.

Optimum reduction temperatures in the range of $600^{\circ} \mathrm{C}$ to $650^{\circ} \mathrm{C}$ have been reported for the limonitic ores [7] [10] [11] [14]. It has also been suggested that this is the minimum temperature for selective reduction, as the reaction kinetics are expected to be prohibitively slow at lower temperatures. The presence of residual crystalline water below $800^{\circ} \mathrm{C}$ may also hinder the formation of metallic nickel [7]. At higher temperatures increased nickel recoveries could be achieved, but the nickel grades significantly decreased as more metallic iron was formed. At lower temperatures, higher nickel recoveries were predicted but it was suggested that the reaction time at these temperatures could be prohibitively long. Canterford et al. [7] calculated that nickel grades up to $65 \%$ could be achieved, depending on the reduction conditions employed. Pickles et al. [14] predicted a similar maximum nickel grade of 70\%, while Swinbourne [15] calculated that smelting of a laterite could yield a ferronickel concentrate containing up to $40 \%$ nickel. While there is significant variation in the ore composition and the amount of reductant employed in each of these studies, they consistently predicted the formation of a high grade ferronickel phase. It should be noted that Canterford and Turnbull [7] and Pickles et al. [14] considered a limonitic ore, while Swinbourne [15] studied a saprolitic ore. The higher magnesium silicate content in the saprolitic ore required higher temperatures to facilitate the extraction of the nickel, but a lower reductant addition was used as there was significantly less iron present to be co-reduced with the nickel. This was supported by the findings of Valix and Cheung [17], who reported that higher temperatures were required for the metallization of iron and nickel in a saprolitic ore than in a limonitic ore. Rhamdhani et al. [13] concluded that in order to achieve maximum nickel recoveries, separate processing streams were necessary for the low- and high-grade saprolitic laterite ores.

Li [12] utilized the $\mathrm{F}{ }^{\star} \mathrm{A}{ }^{*} \mathrm{C}{ }^{\star} \mathrm{T}$ software system to investigate the equilibrium products formed as a result of the reduction of both a limonitic ore and a saprolitic ore in a $\mathrm{CO} / \mathrm{CO}_{2}$ atmosphere at various temperatures. For the same reduction conditions, the limonitic ore exhibited a higher recovery and a lower grade of nickel in the ferronickel, than for the saprolitic ore. For the limonitic ore, decreasing the reduction potential resulted in an increased grade. Similarly, for the saprolitic ore, lowering the reduction potential by lowering the $\mathrm{CO} / \mathrm{CO}_{2}$ ratio resulted in an increased grade. Higher temper- 
atures resulted in increased formation of olivine $\left((\mathrm{Mg}, \mathrm{Fe}, \mathrm{Ni})_{2} \mathrm{SiO}_{4}\right)$ and thus the reduction of nickel oxide was more difficult. For the saprolitic ore and a $\mathrm{CO} / \mathrm{CO}_{2}$ ratio of 2 to 3 , the optimum nickel recovery was achieved in the temperature range of $710^{\circ} \mathrm{C}$ to $740^{\circ} \mathrm{C}$. Also for the saprolite, if the oxygen partial pressure in the gas phase was fixed, then increasing the temperature resulted in a decrease in grade since more iron oxide was reduced than nickel oxide.

More recently, Diaz et al. [17] performed a thermodynamic analysis of the reduction of some Columbian nickeliferous saprolite ores. Three similar ores were considered, with $\mathrm{NiO}$ contents in the range of $1.81 \%$ to $2.59 \%, \mathrm{MgO}$ contents in the range of about $21 \%$ to $23 \%$ and $\mathrm{SiO}_{2}$ contents in the range of about $36 \%$ to $43 \%$. Silica was present as quartz $\left(\mathrm{SiO}_{2}\right)$, antigorite $\left(\mathrm{Mg}_{3} \mathrm{Si}_{2} \mathrm{O}_{5}(\mathrm{OH})_{4}\right)$ and forsterite $\left(\mathrm{Mg}_{2} \mathrm{SiO}_{4}\right)$. The Equilibrium Composition module of $\mathrm{HSC}^{\oplus}$ Chemistry 5.1 was utilized to determine both the nickel grade and the nickel recovery as a function of temperature and also carbon addition. The carbon addition was represented as the $\mathrm{C} / \mathrm{O}$ ratio of the feed, where the oxygen was considered to be the sum of that in both the nickel and iron oxides. The species utilized in the thermodynamic calculations were not indicated and it appears that ideal behavior was assumed for all species. The authors noted that the nickel was in solid solution in the magnesium silicates, for example as nepouite $\left.\left(\mathrm{Ni}_{3} \mathrm{Si}_{2} \mathrm{O}_{5}(\mathrm{OH})_{4}\right)\right)$. However, in their model, the authors do not appear to have accounted for either the expected nonideal behavior of the nickel oxide in the silicates or its effect on the reduction of nickel oxide. Consequently, the majority of the nickel oxide was reduced at the relatively low temperature of $400^{\circ} \mathrm{C}$. Also the non-ideal behaviors of other species were not taken into account. However, based on their thermodynamic calculations, the authors concluded that $99 \%$ of the iron and $100 \%$ of the nickel could be recovered at about $1100^{\circ} \mathrm{C}$ at a $\mathrm{C} / \mathrm{O}$ ratio of unity.

\section{Equilibrium Considerations and Thermodynamic Modelling}

\subsection{Equilibrium Considerations}

As mentioned previously, the reduction behaviours of the two types of laterite ores have been thoroughly reviewed in the literature [5]. Once the ore has been dried and pulverized to the desired particle size, the first stage in the extraction of nickel is the dehydroxylation of the hydrated nickel bearing minerals. In the case of the limonitic ores, the nickel is substituted into the crystal structure of the goethite. The dehydroxylation of goethite occurs at approximately $300^{\circ} \mathrm{C}$ as follows:

$$
2(\mathrm{Fe}, \mathrm{Ni}) \mathrm{O} \cdot \mathrm{OH} \leftrightarrow(\mathrm{Fe}, \mathrm{Ni})_{2} \mathrm{O}_{3}+\mathrm{H}_{2} \mathrm{O}
$$

Upon dehydroxylation, the nickel is incorporated into the new hematite structure [18]. Under mildly reducing conditions, however, the nickel will be incorporated into the spinel phase [13] [20] as follows:

$$
6(\mathrm{Fe}, \mathrm{Ni}) \mathrm{O} \cdot \mathrm{OH} \leftrightarrow 2(\mathrm{Fe}, \mathrm{Ni})_{3} \mathrm{O}_{4}+3 \mathrm{H}_{2} \mathrm{O}+0.5 \mathrm{O}_{2}
$$

In the case of the saprolitic ores, the analogous dehydroxylation of the garnierite occurs at much higher temperatures of between $650^{\circ} \mathrm{C}$ and $810^{\circ} \mathrm{C}$, as follows: 


$$
(\mathrm{Mg}, \mathrm{Fe}, \mathrm{Ni})_{3} \mathrm{Si}_{2} \mathrm{O}_{5}(\mathrm{OH})_{4} \leftrightarrow(\mathrm{Mg}, \mathrm{Fe}, \mathrm{Ni}) \mathrm{SiO}_{3}+(\mathrm{Mg}, \mathrm{Fe}, \mathrm{Ni})_{2} \mathrm{SiO}_{4}+2 \mathrm{H}_{2} \mathrm{O}
$$

This dehydroxylation process is significantly more complex than that of the limonitic ore, resulting in the formation of both olivine $\left(\left(\mathrm{Mg}, \mathrm{Fe}, \mathrm{Ni}_{2}\right)_{2} \mathrm{SiO}_{4}\right)$ and pyroxene $((\mathrm{Mg}$, $\mathrm{Fe}, \mathrm{Ni}) \mathrm{SiO}_{3}$ ) [19] [21]. Both iron and nickel substitute for magnesium in the crystal structure of the resulting minerals. In addition to this above reaction, Rhamdhani et al. [13] reported that garnierite can decompose according to the following reaction:

$$
(\mathrm{Mg}, \mathrm{Fe}, \mathrm{Ni})_{3} \mathrm{Si}_{2} \mathrm{O}_{5}(\mathrm{OH})_{4} \leftrightarrow 3(\mathrm{Mg}, \mathrm{Fe}, \mathrm{Ni})_{2} \mathrm{SiO}_{4}+\mathrm{SiO}_{2}+4 \mathrm{H}_{2} \mathrm{O}
$$

In this case, pyroxene is absent and only olivine forms in the presence of considerable free silica. Ball and Taylor [22] originally reported the possibility of the formation of a more easily reduced intermediate amorphous phase, where the recrystallization of the magnesium species did not occur, and neither olivine nor pyroxene were formed, according to the following reaction:

$$
9(\mathrm{Mg}, \mathrm{Fe}, \mathrm{Ni})_{3} \mathrm{Si}_{2} \mathrm{O}_{5}(\mathrm{OH})_{4} \leftrightarrow 9(\mathrm{Mg}, \mathrm{Fe}, \mathrm{Ni})_{3} \mathrm{Si}_{2} \mathrm{O}_{7}+18 \mathrm{H}_{2} \mathrm{O}
$$

It would be expected that the amount and type of the nickel oxide-containing mineral (or minerals) would have a significant effect on the reduction behaviour of the nickel oxide.

Once the crystalline water has been removed from the ore, then the reduction of the nickel oxide to nickel metal can be achieved by reaction with a variety of reagents, such as carbon, hydrogen or methane. In the case of solid carbon, most of the reduction of the nickel oxide is likely performed by carbon monoxide. For the limonitic laterite ore, the reduction reaction for the nickel bearing spinel by carbon monoxide is as follows:

$$
\mathrm{NiFe}_{2} \mathrm{O}_{4}+\mathrm{CO} \leftrightarrow \mathrm{Ni}+\mathrm{Fe}_{2} \mathrm{O}_{3}+\mathrm{CO}_{2}
$$

The iron oxides contained in the ore will also be reduced:

$$
\begin{aligned}
3 \mathrm{Fe}_{2} \mathrm{O}_{3}+\mathrm{CO} & \leftrightarrow 2 \mathrm{Fe}_{3} \mathrm{O}_{4}+\mathrm{CO}_{2} \\
\mathrm{Fe}_{3} \mathrm{O}_{4}+\mathrm{CO} & \leftrightarrow 3 \mathrm{FeO}+\mathrm{CO}_{2} \\
\mathrm{FeO}+\mathrm{CO} & \leftrightarrow \mathrm{Fe}+\mathrm{CO}_{2} \\
\mathrm{Fe}_{3} \mathrm{O}_{4}+4 \mathrm{CO} & \leftrightarrow 3 \mathrm{Fe}+4 \mathrm{CO}_{2}
\end{aligned}
$$

The hematite in the dehydroxylated ore will first be reduced to magnetite $\left(\mathrm{Fe}_{3} \mathrm{O}_{4}\right)$, and then potentially further to wüstite $(\mathrm{FeO})$ and finally to metallic iron $(\mathrm{Fe})$, given sufficient reduction potential and temperature. It is also possible for the iron silicates, such as fayalite $\left(\mathrm{Fe}_{2} \mathrm{SiO}_{4}\right)$, to be reduced as follows:

$$
\mathrm{Fe}_{2} \mathrm{SiO}_{4}+2 \mathrm{CO} \leftrightarrow 2 \mathrm{Fe}+\mathrm{SiO}_{2}+2 \mathrm{CO}_{2}
$$

However, this requires elevated temperatures and reduction potentials. For the saprolite ore, possible reactions describing the reduction of olivine and pyroxene, respectively are as follows:

$$
\begin{gathered}
\left(\mathrm{Ni}_{x} \mathrm{Mg}_{1-x}\right) 2 \mathrm{SiO}_{4}+2 x \mathrm{CO} \leftrightarrow 2 x \mathrm{Ni}+2 x \mathrm{SiO}_{2}+\mathrm{Mg}_{2-2 x} \mathrm{Si}_{1-2 x} \mathrm{O}_{4-2 x}+2 x \mathrm{CO}_{2} \\
\left(\mathrm{Ni}_{x} \mathrm{Mg}_{1-x}\right) \mathrm{SiO}_{3}+x \mathrm{CO} \leftrightarrow x \mathrm{Ni}+x \mathrm{SiO}_{2}+(1-x) \mathrm{MgSiO}_{3}+x \mathrm{CO}_{2}
\end{gathered}
$$

The reduction of the nickel oxide from the mineral results in the production of a 
small amount of free silica.

\subsection{Stability Diagrams}

Jivasek and Pedlik [8] were one of the first to develop a computer program in order to calculate pressure versus temperature stability diagrams for the $\mathrm{Fe}-\mathrm{Ni}$-Co lateritic ores. They produced diagrams for the Fe-Ni-Co-O-H system and the Fe-O-H, Ni-O-H and Co-O-H subsystems. More recently, Hallet [11] performed a thermodynamic analysis of the reduction of both a limonitic and a saprolitic laterite ore, developing predominance area diagrams for both the $\mathrm{Fe}-\mathrm{Ni}-\mathrm{O}$ and $\mathrm{Ni}-\mathrm{Mg}-\mathrm{SiO}_{2}$ systems, as shown in Figure 1 and Figure 2, respectively. These diagrams can be used as reduction maps for the extraction of nickel metal from the corresponding ore type.

As several authors have noted, manipulation of the reduction conditions can be used to achieve a high nickel grade ferronickel product. However, it is also relevant to review the other species, which will be formed under the same conditions, particularly when considering what method is to be used to recover the alloy phase. For the limonitic ore, Figure 1 shows five phase fields: spinel solid solution, wüstite solid solution, alloy, spinel plus alloy and wüstite plus alloy. Spinel predominates at low reduction potentials. As the reduction potential is increased at low temperatures, some alloy is produced and eventually there is complete conversion to alloy. At higher temperatures, the spinel is reduced to wüstite plus alloy and again completely alloy. Under some conditions the nickel can be reoxidized back into the wüstite phase. At the optimal reduction temperature $\left(\sim 600^{\circ} \mathrm{C}\right)$ noted by other researchers [7] [10], the stable iron species will be either magnetite or metallic iron for a significant range of reduction potentials. For similar reduction conditions (equal temperature and $\mathrm{CO}: \mathrm{CO}_{2}$ ratio), significantly lower nickel metallization is predicted for the saprolitic ore, despite the higher nickel grade

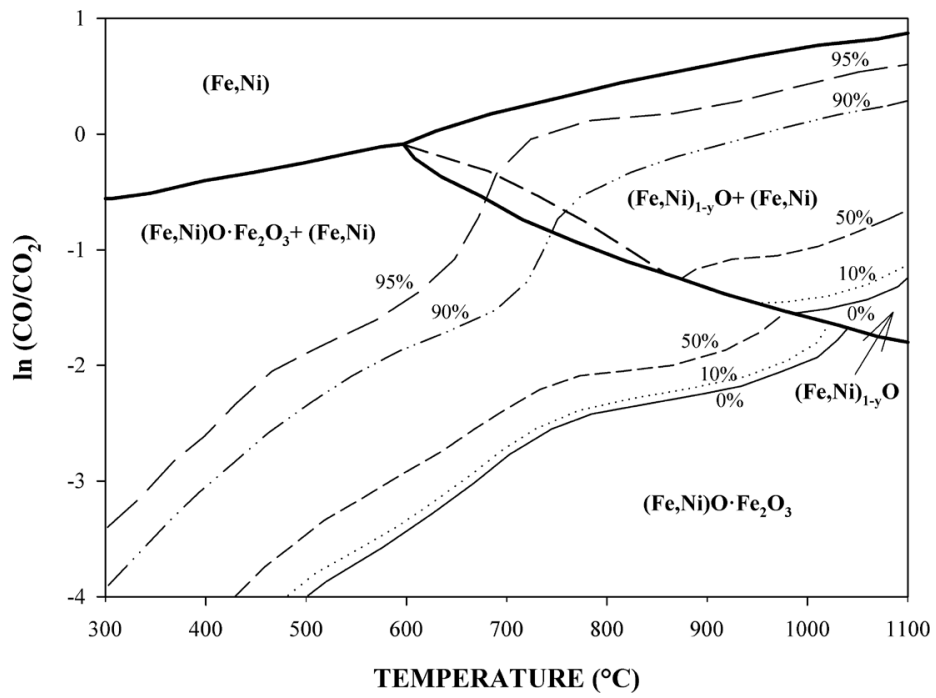

Figure 1. The Fe-Ni-O stability diagram for goethite containing $1.2 \% \mathrm{Ni}$ with $\mathrm{Ni}$ metallization curves of $0 \%, 10 \%, 50 \%, 90 \%$ and $95 \%$. Adapted from Hallet [11]. 


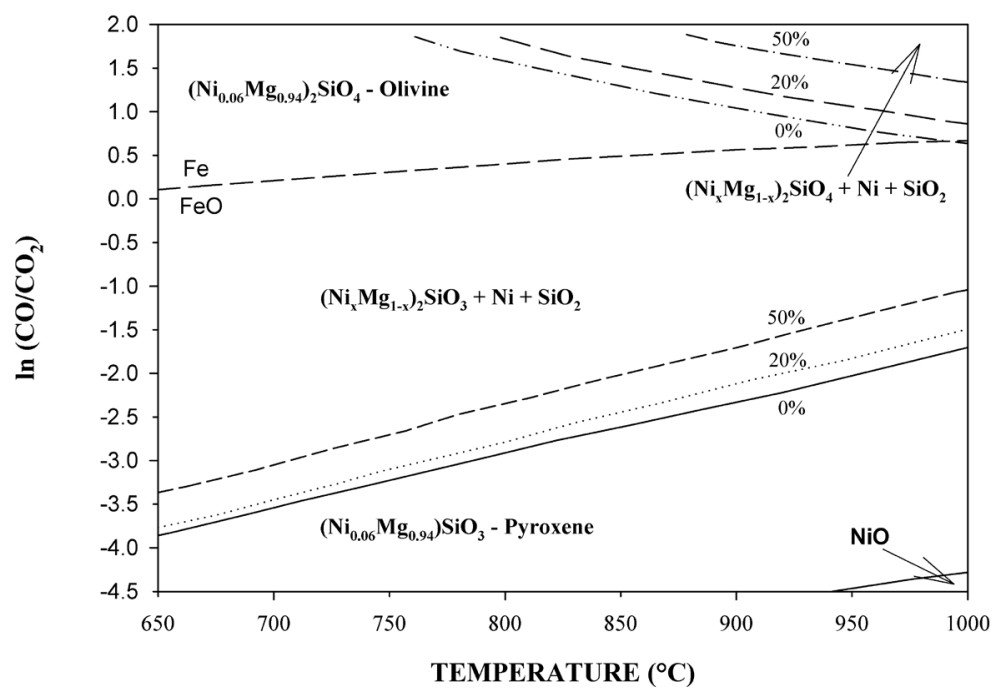

Figure 2. The Ni-Mg-Si-O stability diagram for olivine and pyroxene from a decomposed saprolite containing $4 \% \mathrm{Ni}$ with Ni metallization curves of $0 \%, 20 \%$ and $50 \%$. Adapted from Hallet [11].

in the feed material (Figure 2), as the high silicate saprolitic ores require higher processing temperatures [9]. For most saprolite compositions, decomposition will result in the formation of either olivine and/or pyroxene. The Ni-Mg-Si-O diagram shown in Figure 2 has four phase fields: pyroxene, decomposed pyroxene plus silica plus nickel metal, olivine, and decomposed olivine plus silica plus nickel metal. The boundary in the lower right corner is for the reduction of nickel oxide to nickel. The boundary at the top of the diagram is for the reduction of wüstite to pure iron. Pyroxene exists at low reduction potentials across the entire temperature range. As the reducing potential increases, the pyroxene is reduced and nickel metal begins to form. For the case of olivine, nickel metallization only occurs at both high temperatures and high $\mathrm{CO} / \mathrm{CO}_{2}$ ratios. Hallet (1997) also reported that the reduction of nickel in silicate-bearing minerals was more complicated as compared to that of the limonitic ore. If the garnierite decomposes to olivine, then stronger reducing conditions are required for nickel metallization as compared to pyroxene. Compared to the reduction of wüstite to iron, pyroxene is easier to reduce to nickel, while olivine is more difficult.

\subsection{Thermodynamic Modelling}

A thermodynamic model has previously been developed for the carbothermic reduction of a limonitic ore and details of this model have been reported by Pickles et al. [14]. The current model expands upon this prior simulation to allow for more accurate prediction of the behavior of the saprolitic ores, with their higher magnesium silicate contents. The Equilibrium Composition program of $\mathrm{HSC}^{\circledast} 6.1$ was utilized to determine the equilibrium amounts of the products, resulting from the carbothermic reduction of the two ore types. This program utilizes the free energy minimization technique at a constant pressure and temperature. The limonitic and saprolitic ores were assumed to be 
comprised of $\mathrm{Ni}, \mathrm{Fe}, \mathrm{Co}, \mathrm{Mg}, \mathrm{Si}, \mathrm{Al}$, and $\mathrm{O}$. Carbon (C) was added as the reducing agent. Inputting these elements into the Equilibrium Composition program of $\mathrm{HSC}^{\circledR} 6.1$ yielded 212 possible species. The majority of these were unstable under the conditions in the current carbothermic reduction roasting process and therefore only the twenty-six species shown in Table 1 were used. The compositions employed for the limonitic and saprolitic ores are shown in Table 2. As expected, the saprolitic ore has a higher nickel oxide content than the limonitic ore, but a lower iron oxide content. Also, the saprolitic ore has significantly higher magnesia and silica contents.

With regards to the ore composition, $\mathrm{CaO}$ was assumed to behave in a manner similar to $\mathrm{MgO}$ and other minor impurities were included with $\mathrm{Al}_{2} \mathrm{O}_{3}$. Also for the purposes of this study, the ore was assumed to be calcined, since at the temperatures of reduction the hydrated minerals would have been dewatered and the majority of the water vapour would have left the system. Cobalt was assumed to behave in a manner similar to nickel. For the basis of comparison, the carbon addition utilized for each ore was the stoichiometric requirement for the reduction of the iron oxide $\left(\mathrm{Fe}_{2} \mathrm{O}_{3}\right)$ in the ore to wüstite $(\mathrm{FeO})$ and the nickel oxide $(\mathrm{NiO})$ to nickel metal, according to the following Equations:

$$
\begin{gathered}
\mathrm{Fe}_{2} \mathrm{O}_{3}+\mathrm{C} \leftrightarrow 2 \mathrm{FeO}+\mathrm{CO} \\
\mathrm{NiO}+\mathrm{C} \leftrightarrow \mathrm{Ni}+\mathrm{CO}
\end{gathered}
$$

In this way, low temperature solid state reduction could be performed in order to recover the majority of the nickel and magnetite formation could be avoided, which would allow subsequent magnetic separation to produce a high grade nickel concentrate. For the limonitic ore, the stoichiometric carbon requirement was $7.07 \mathrm{~kg} / 100 \mathrm{~kg}$ of ore, while for the saprolitic ore it was $2.76 \mathrm{~kg} / 100 \mathrm{~kg}$ of ore.

Table 1. Summary of phases (in bold) and species considered in the thermodynamic calculations.

\begin{tabular}{cccc}
\hline GAS & OXIDES & OXIDES & OXIDES \\
\hline $\mathrm{CO}$ & $\mathrm{CoO}$ & $\mathrm{FeSiO}_{3}$ & $\mathrm{Mg}_{2} \mathrm{SiO}_{4}$ \\
$\mathrm{CO}_{2}$ & $\mathrm{CoFe}_{2} \mathrm{O}_{4}$ & $\mathrm{Fe}_{2} \mathrm{SiO}_{4}$ & $\mathrm{MgSiO}_{3}$ \\
$\mathrm{O}_{2}$ & $\mathrm{FeO}$ & $\mathrm{MgFe}_{2} \mathrm{O}_{4}$ & $\mathrm{NiO}_{(\mathrm{ol})}$ \\
$\mathrm{ALLOY}$ & $\mathrm{Fe} \mathrm{O}_{4}$ & $\mathrm{MgO}$ & $\mathrm{NiO}_{(\mathrm{py})}$ \\
$\mathrm{Fe}$ & $\mathrm{Fe}_{2} \mathrm{O}_{3}$ & $\mathrm{SiO}_{2}$ & $\mathrm{NiFe}_{2} \mathrm{O}_{4}$ \\
$\mathrm{Ni}$ & $\mathrm{FeO}_{\mathrm{SiO}}$ & $\mathrm{Al}_{2} \mathrm{O}_{3}$ & $\mathrm{CARBON}$ \\
$\mathrm{Co}$ & $2 \mathrm{FeO} \cdot \mathrm{SiO}_{2}$ & $\mathrm{Al}_{2} \mathrm{O}_{3} \cdot \mathrm{SiO}_{2}$ & $\mathrm{C}$ \\
\hline
\end{tabular}

Table 2. Composition of the limonitic and saprolitic laterite ores considered in the present work (limonitic from [23]; saprolitic from [24]).

\begin{tabular}{ccccccc}
\hline Component & $\mathrm{NiO}$ & $\mathrm{Fe}_{2} \mathrm{O}_{3}$ & $\mathrm{CoO}$ & $\mathrm{MgO}$ & $\mathrm{SiO}_{2}$ & $\mathrm{Al}_{2} \mathrm{O}_{3}$ \\
\hline Limonite & 1.31 & 91.10 & 0.08 & 0.81 & 4.40 & 2.30 \\
Saprolite & 2.77 & 30.74 & 0.08 & 18.09 & 42.08 & 6.33 \\
\hline
\end{tabular}


Unless specified, the Equilibrium Composition program assumes an activity coefficient of unity for each species. In previous research on modelling the nickeliferous limonitic laterite ores, activity coefficients for the spinel $\left(\mathrm{NiFe}_{2} \mathrm{O}_{4}\right)[25]$, oxide $((\mathrm{Fe}, \mathrm{Ni})$ O) [26] and metal phase (Fe-Ni) [27] have been derived from information in the literature and were included in the model. In the current saprolite model, the nickel oxide was assumed to potentially occur in two forms: $\mathrm{NiO}$ dissolved in pyroxene $\left(\mathrm{NiO}_{(\mathrm{py})}\right)$; and $\mathrm{NiO}$ dissolved in olivine $\left(\mathrm{NiO}_{(\mathrm{ol})}\right)$. The activities of $\mathrm{NiO}$ in both pyroxene $\left(\mathrm{MgSiO}_{3}\right)$ and olivine $\left(\mathrm{Mg}_{2} \mathrm{SiO}_{4}\right)$ have been measured by Shirane et al. [28]. From these activity values, the activity coefficients of $\mathrm{NiO}$, for input into the HSC software, have been determined as a function of temperature and composition as follows:

$$
\begin{aligned}
& \ln \gamma_{\mathrm{NiO}(\mathrm{py})}=(7.1-0.005 \mathrm{~T})+(-92.9+0.070 \mathrm{~T}) \mathrm{X}_{\mathrm{NiO}(\mathrm{py})} \\
& \ln \gamma_{\mathrm{NiO}(\mathrm{ol})}=(-17.7+0.012 \mathrm{~T})+(11.8-0.008 \mathrm{~T}) \mathrm{X}_{\mathrm{NiO}(\mathrm{ol})}
\end{aligned}
$$

Nickel oxide in pyroxene exhibits positive deviation from ideality, but the $\mathrm{a}_{\mathrm{NiO}(\mathrm{py})}$ decreases with increasing temperature and consequently ideality is approached at high temperatures. On the other hand, nickel oxide in olivine exhibits negative deviation from ideal behavior, however the $\mathrm{a}_{\mathrm{NiO}(\mathrm{ol})}$ increases with temperature and thus again approaches ideality at high temperatures. $\mathrm{NiO}_{(\mathrm{ol})}$ and $\mathrm{NiO}_{(\mathrm{py})}$ were not included when modelling the limonite, as the nickel will be primarily contained within the nickel ferrite $\left(\mathrm{NiFe}_{2} \mathrm{O}_{4}\right)$.

\section{Results and Discussion}

\subsection{Effect of Reduction Temperature}

Figure 3(a) and Figure 3(b) show the nickel and iron recoveries and the nickel grade of the ferronickel as a function of temperature for the limonitic ore and the saprolite ore, respectively. For the limonitic ore, nickel metal forms at about $430^{\circ} \mathrm{C}$, reflecting the relatively low stability of the nickel oxide. Subsequently, the nickel recovery increases rapidly with temperature to about $95 \%$ at $600^{\circ} \mathrm{C}$, then slows down and eventually levels off at about $99 \%$ at $700^{\circ} \mathrm{C}$. Although metallic iron also simultaneously forms at $430^{\circ} \mathrm{C}$, at the outset it is produced in relatively small amounts, with the recovery increasing slowly to about $2 \%$ at $670^{\circ} \mathrm{C}$, then more rapidly before reaching a maximum value of $32 \%$ again at a temperature of $700^{\circ} \mathrm{C}$. Thereafter, the iron recovery decreases slowly with increasing temperature. As a result, the nickel grade initially increases very rapidly to about $94 \%$ at $430^{\circ} \mathrm{C}$, decreases to $5 \%$ at about $700^{\circ} \mathrm{C}$ and then remains relatively constant with increasing temperature. It can be seen that high nickel recoveries of $90 \%$ to $95 \%$ and high grades of $50 \%$ to $80 \%$ can be achieved in the temperature range of $550^{\circ} \mathrm{C}$ to $650^{\circ} \mathrm{C}$ However, in order to achieve nickel recoveries approaching $100 \%$, temperatures of over $700^{\circ} \mathrm{C}$ are required and under these conditions significant iron is also reduced and this leads to the low nickel grades of about $5 \%$.

For the saprolitic laterite ore as shown in Figure 3(b), metallic iron and nickel do not form until the much higher temperature of about $800^{\circ} \mathrm{C}$, in contrast with the limo- 
nitic ore where metallic nickel and iron form at about $430^{\circ} \mathrm{C}$. About $65 \%$ of the nickel is reduced over the narrow temperature range from $800^{\circ} \mathrm{C}$ to $825^{\circ} \mathrm{C}$. Thereafter and very quickly, the nickel recovery begins to slow down due to the high stability of the remaining nickel oxide in the olivine. The recovery reaches a maximum value of only about $92 \%$ at $1150^{\circ} \mathrm{C}$ and then begins to decrease as some nickel oxide is re-oxidized into the magnesium silicates. In a manner similar to nickel oxide, the majority of the reduction of the iron oxide to metallic iron occurs rapidly from about $800^{\circ} \mathrm{C}$ to $825^{\circ} \mathrm{C}$. The iron recovery reaches a maximum value of only about $9 \%$ at $825^{\circ} \mathrm{C}$ and then decreases slowly with increasing temperature. Since the iron recovery is low and not a strong function of temperature, then the nickel grade of the ferronickel is essentially independent of temperature. At $825^{\circ} \mathrm{C}$ the nickel grade of the ferronickel is about $40 \%$ and then slowly increases with increasing temperature before levelling off at about 53\% at $1150^{\circ} \mathrm{C}$.

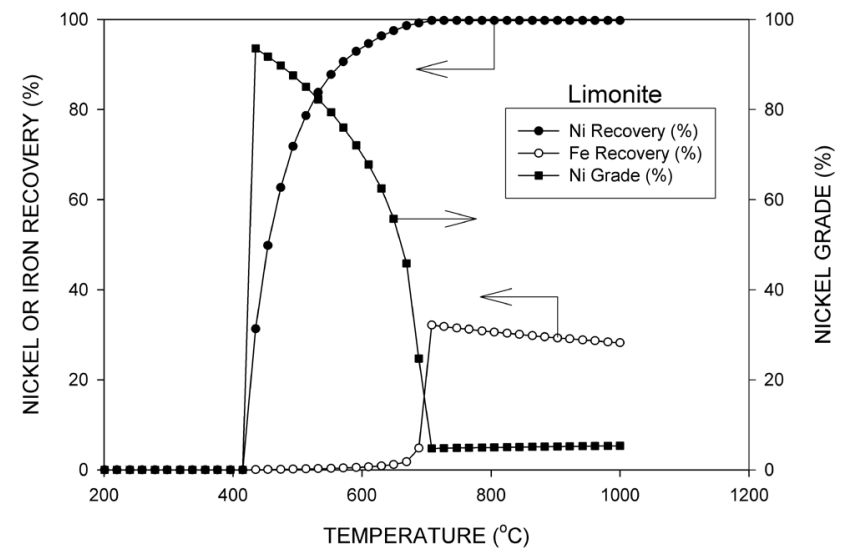

(a)

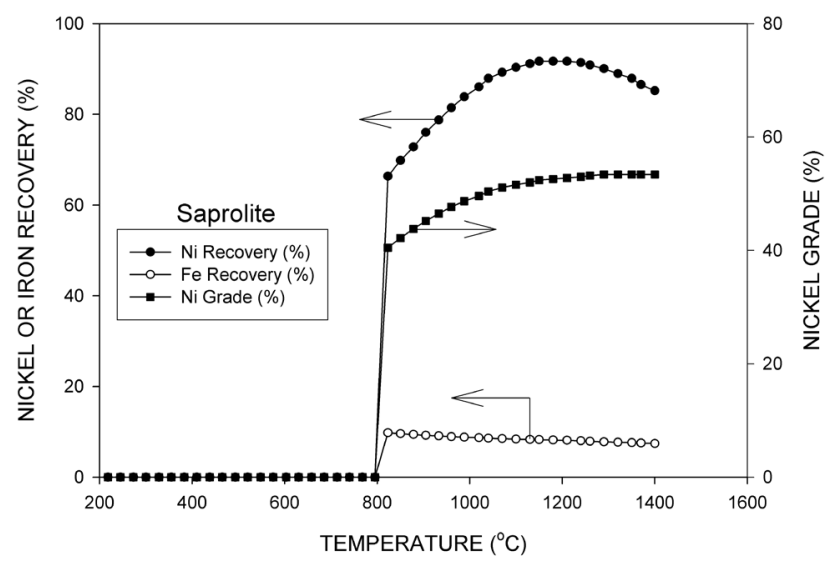

(b)

Figure 3. (a) Nickel recovery, iron recovery and nickel grade of the ferronickel as a function of temperature for the limonitic laterite ore with $7.07 \mathrm{~kg}$ carbon per $100 \mathrm{~kg}$ of ore; (b) Nickel recovery, iron recovery and nickel grade of the ferronickel as a function of temperature for the saprolitic laterite ore with $2.76 \mathrm{~kg}$ carbon per $100 \mathrm{~kg}$ of ore. 
A comparison of the reduction behaviors of the two ore types shows that the concurrent reduction of both nickel and iron occur at much lower temperatures in the limonitic ore than in the saprolitic ore. This reflects the lower stability of nickel oxide in the nickel ferrite as compared to the nickel oxide in the magnesium silicates. For the limonitic ore, the majority of the nickel is reduced over the relatively low and wide temperature range from $430^{\circ} \mathrm{C}$ to $700^{\circ} \mathrm{C}$, with very little iron being recovered. High nickel grades and recoveries are possible at low temperatures, but over a relatively narrow temperature range from about $550^{\circ} \mathrm{C}$ to about $650^{\circ} \mathrm{C}$ for which the reaction kinetics would be expected to be slow. If higher nickel recoveries approaching $99 \%$ are desired, then in this higher temperature range the iron recovery increases and this lowers the grade of the ferronickel. On the other hand, for the saprolitic ore, significant nickel recoveries of about $65 \%$ are possible between about $800^{\circ} \mathrm{C}$ to $825^{\circ} \mathrm{C}$ but thereafter the nickel recovery increases very slowly with temperature and recoveries of about $90 \%$ can only be achieved at about $1150^{\circ} \mathrm{C}$. However, because of the much lower iron oxide content of the saprolite, the lower iron recoveries and the higher nickel oxide content, in comparison to the limonite, the nickel grade of the ferronickel is higher than that obtained for the limonite at these higher temperatures. For the limonitic ore, a high nickel recovery of $99 \%$ can be achieved at $680^{\circ} \mathrm{C}$ with a nickel grade of the ferronickel of about $14 \%$. On the other hand, for the saprolitic ore, nickel recoveries of $92 \%$ can only be achieved at $1150^{\circ} \mathrm{C}$ with a nickel grade of the ferronickel of $52 \%$.

Figure 4(a) and Figure 4(b) show the behaviors of the iron-containing species for the limonitic ore and the saprolitic laterite ore, respectively, as a function of temperature. The initial limonitic laterite ore has a large amount of iron oxide, while the initial saprolitic laterite has a low amount of iron oxide and a large amount of silica. For the reduction of the limonitic ore, hematite and magnetite predominate at low temperatures. As the temperature increases, the amounts of wüstite and iron silicate $(2 \mathrm{FeO}$. $\mathrm{SiO}_{2}$ ) increase at the expense of the hematite and magnetite. Above about $650^{\circ} \mathrm{C}$, where a significant amount of metallic iron forms, the amounts of magnetite and $2 \mathrm{FeO} \cdot \mathrm{SiO}_{2}$ remain relatively constant, while the amount of wüstite continues to increase at the expense of the metallic iron. Although the amount of magnetite decreases with increasing temperature, it remains present in relatively high amounts across the whole temperature range. For the saprolitic laterite ore, again hematite and magnetite predominate at low temperatures, but the magnetite begins to decrease and completely disappears by about $700^{\circ} \mathrm{C}$. Because of the large amount of silica in the ore, iron silicates $\left(\mathrm{FeSiO}_{3}\right.$ and $2 \mathrm{FeO} \cdot \mathrm{SiO}_{2}$ ) are present in relatively large amounts, with their amounts decreasing after the appearance of metallic iron. Generally, the amount of wüstite increases continuously with temperature. For the saprolitic ore, the lower amount of iron oxide and the higher amounts of iron silicates, in comparison to the limonitic ore, limits the amount of iron oxide reduced to metallic iron and thus higher grades can be achieved at the higher reduction temperatures. Additionally, magnetite forms in both cases at low temperatures, but for the saprolitic ore it is not present at high temperatures, while for the limonitic ore the amount increases significantly with increasing temperature. 
Thus, if it is desired to concentrate the product of solid state reduction by magnetic separation, it should be easier to produce a high grade concentrate from the saprolitic ore. Careful control of the reduction conditions would be necessary to minimize the amount of magnetite formed during the reduction of the limonitic ore.

Figure 5(a) and Figure 5(b) show the behavior of the gaseous species as well as carbon and metallic iron for the limonitic ore and the saprolitic ore, respectively, as a function of temperature. In both cases, the behavior of carbon is similar. At low temperatures, carbon coexists with carbon dioxide, and as the temperature increases the amount of carbon decreases and the amount of carbon dioxide increases. At about $500^{\circ} \mathrm{C}$, increasing amounts of carbon monoxide are produced and this results in a de-

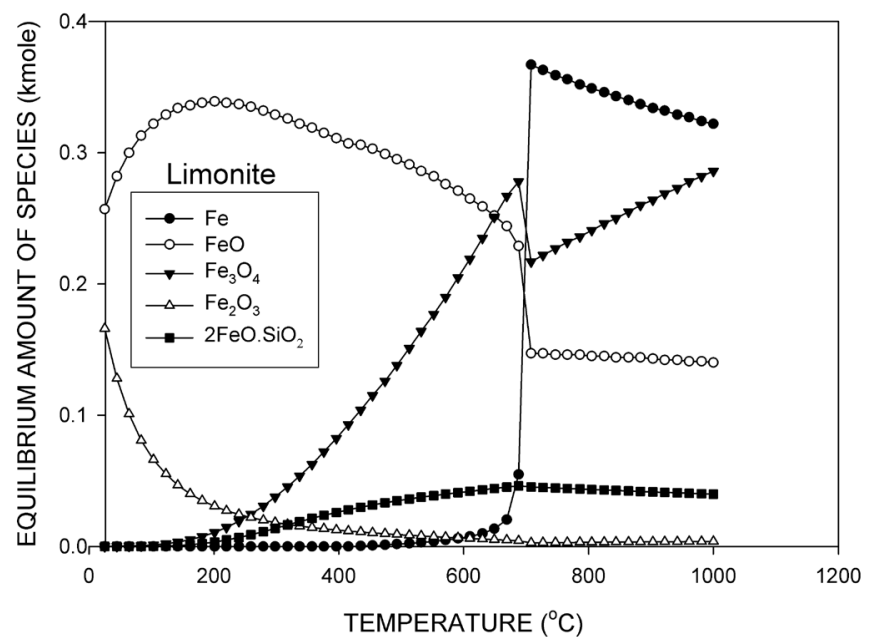

(a)

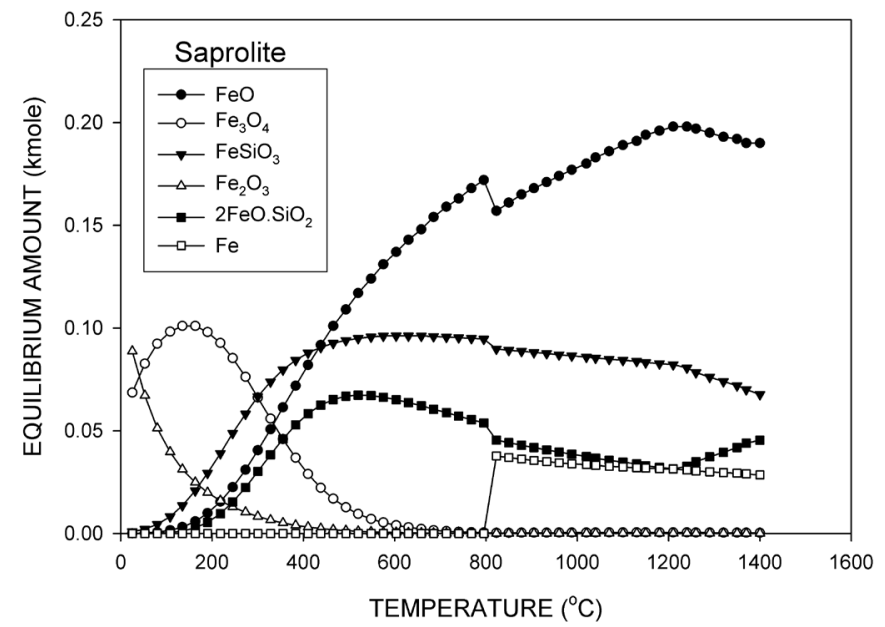

(b)

Figure 4. (a) Iron species as a function of temperature during the reduction of the limonitic laterite ore with $7.07 \mathrm{~kg}$ of carbon per $100 \mathrm{~kg}$ of ore; (b) Iron species as a function of temperature during the reduction of the saprolitic laterite ore with $2.76 \mathrm{~kg}$ carbon per $100 \mathrm{~kg}$ of ore. 
crease in the amount of carbon dioxide. The amount of carbon continues to decrease and the disappearance of carbon corresponds to the maximum recovery of metallic iron. As the iron oxide is reduced to metallic iron, the amount of carbon decreases rapidly to an insignificant amount, while the amount of carbon monoxide increases rapidly and the amount of carbon dioxide decreases. In both cases, the majority of metallic iron formation occurs around $700^{\circ} \mathrm{C}$. Subsequently, the amount of carbon monoxide increases while the amounts of carbon dioxide and metallic iron decrease for the limonitic laterite. For the saprolite, these amounts remain relatively constant with increasing temperature. This behavior reflects the higher amount of iron oxide in the limonitic laterite in comparison to the saprolitic laterite.

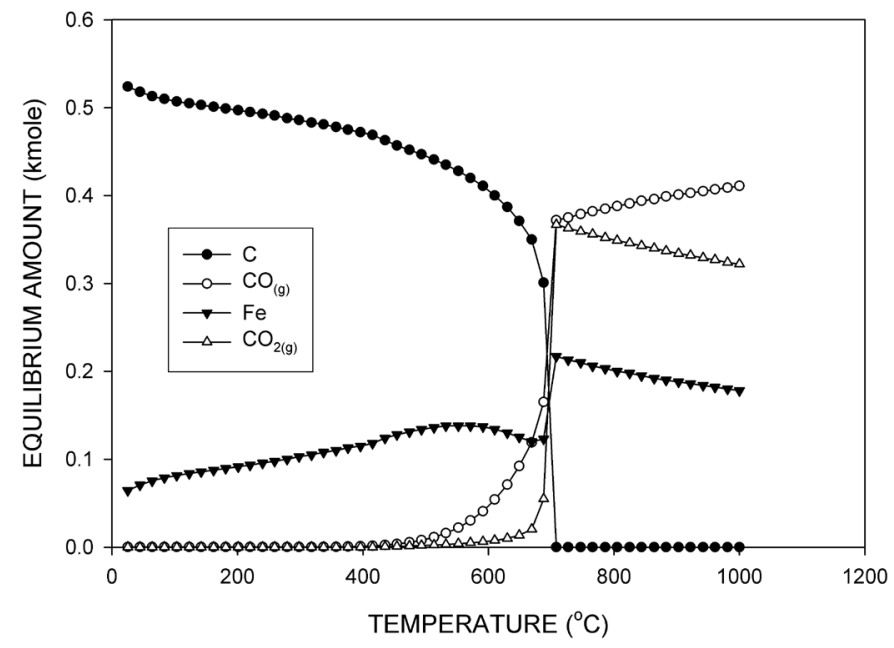

(a)

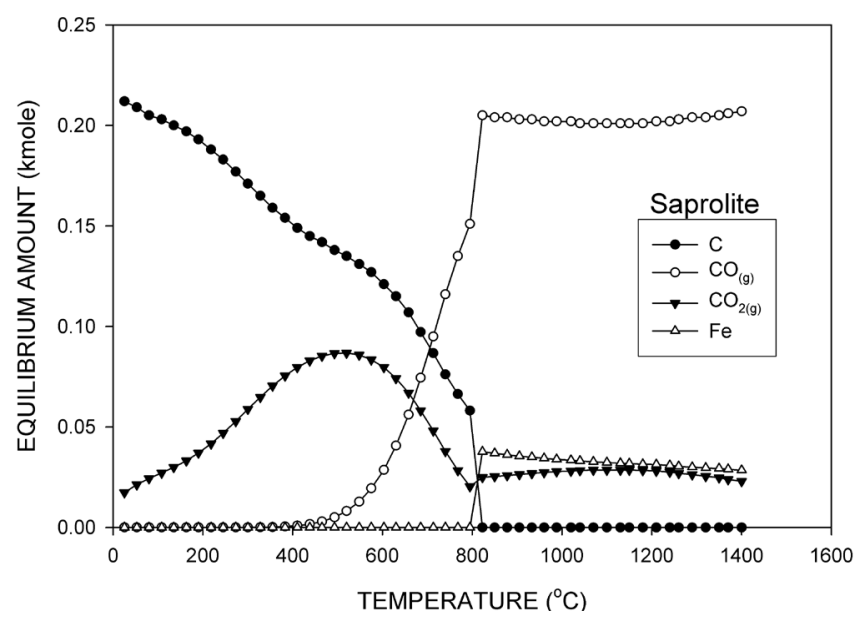

(b)

Figure 5. (a) Gaseous species, carbon and metallic iron as a function of temperature during the reduction of a limonitic laterite ore with $7.07 \mathrm{~kg}$ carbon per $100 \mathrm{~kg}$ of ore; (b) Gaseous species, carbon and metallic iron as a function of temperature during the reduction of a saprolitic laterite ore with $2.76 \mathrm{~kg}$ carbon per $100 \mathrm{~kg}$ of ore. 
From the above discussion, it can be seen that for the limonitic ores, high nickel recoveries can be achieved at relatively low temperatures but the reaction kinetics would likely be slow. As the temperature is increased, the nickel recovery increases slightly, but the iron recovery becomes relatively high and therefore the grade of the ferronickel is lowered. On the other hand, for the saprolitic ores, high recoveries can only be achieved at relatively high temperatures but because of the lower iron oxide content and the high silica content, higher nickel grades are possible in the ferronickel. Thus, one processing option is to blend the two ores and potentially obtain high nickel recoveries and grades at intermediate temperatures. In this regard, the model for the limonitic ore and the saprolitic ore were combined and the recoveries and grades were determined for a blended ore containing $50 \%$ of the limonitic ore and $50 \%$ of the saprolitic ore. The carbon requirement was maintained as the stoichiometric requirement as given previously by Equations 10 and 11. The nickel recoveries and the grades of the ferronickel are shown in Figure 6(a) and Figure 6(b), for the limonitic ore, the sapro-

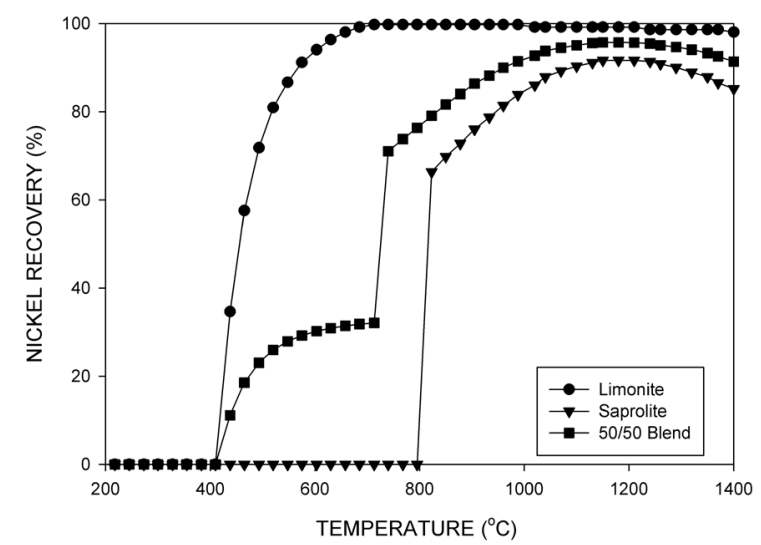

(a)

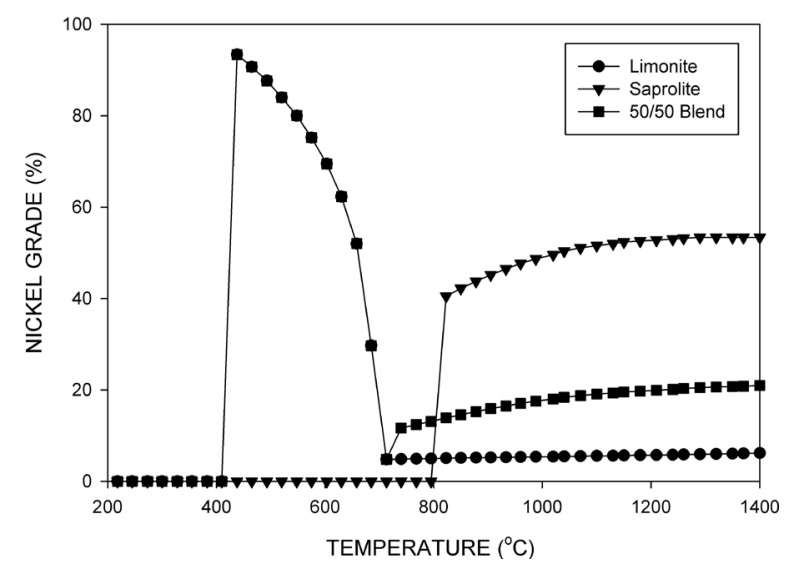

(b)

Figure 6. (a) Nickel recoveries as a function of temperature for the limonitic and saprolitic ores and a blended limonitic and saprolitic ore (50/50); (b) Nickel grade of the ferronickelas a function of temperature for the limonitic and saprolitic ores and a blended limonitic plus saprolitic ore (50/50). 
litic ore and the 50/50 blend, respectively. It can be seen that nickel recoveries of about $90 \%$ and nickel grades of about $17 \%$ in the ferronickel can be achieved at about $950^{\circ} \mathrm{C}$, while at $1150^{\circ} \mathrm{C}$, the nickel recovery is about $96 \%$ and the nickel grade is about $20 \%$. Thus, a comparison of these results with those for the limonitic ore and also for the saprolitic ore shows that blending of the ore can result in higher nickel recoveries at lower temperatures than for the saprolitic ore alone, but at higher temperatures than for the limonitic ore alone. On the other hand, for the blended ore, the grade is lower than for the saprolitic ore but higher than for the limonitic ore. It can be seen from the recovery and grade results in Figure 6(a) and Figure 6(b), that for the blended ore, the limonitic ore portion is reduced first at lower temperatures and then the saprolitic ore portion at higher temperatures. However, the presence of the increased amount of iron oxide and hence an increased amount of metallic iron from the limonitic ore, lowers the reduction temperature of the nickel oxide from the saprolitic ore. Thus, at a given temperature, higher recoveries can be achieved for the blended ore than for the saprolitic ore alone, but the increased amount of metallic iron lowers the grade of the ferronickel.

\subsection{Effect of Ore Composition and Carbon Additions}

The compositions of both the limonitic and the saprolitic laterite ores can vary over wide ranges and therefore this variable was investigated. For the limonitic ore, the nickel content can vary from about $1 \%$ to $2 \%$ and the iron can vary from about $40 \%$ to $60 \%$. Here the iron content is mainly determined by the amount of silica present. For the saprolitic ore, the nickel content can vary from about $2 \%$ to $4 \%$ and the iron from $15 \%$ to $30 \%$, while the magnesia and silica contents can vary from $15 \%$ to $25 \%$ and $35 \%$ to $45 \%$, respectively. The control ore compositions were those as used previously and the composition of the species of interest was varied. For the limonitic ore a reduction temperature of $600^{\circ} \mathrm{C}$ was utilized, while for the saprolitic ore the temperature was $1150^{\circ} \mathrm{C}$.

Figures 7(a) and Figure 7(b) show the effects of the nickel oxide content on the nickel recovery and the grade of the ferronickel for the limonitic ore and the saprolitic ore, respectively. For the limonitic ore, the recovery increased somewhat with increasing nickel oxide content with this effect being more pronounced at lower nickel oxide contents. On the other hand, the grade showed only a slight increase with increasing nickel oxide content. The equilibrium amounts of nickel oxide and nickel ferrite remained essentially constant with increasing nickel oxide content and thus proportionately more nickel was recovered with increasing nickel oxide content of the ore. However, because of the large amount of iron oxide present, the increased amount of nickel recovered did not affect the grade. Conversely, increasing the nickel oxide content of the saprolitic ore resulted in a decreased recovery of nickel, since the equilibrium amounts of nickel oxide in the magnesium silicates increased with increasing nickel oxide content of the ore. However, since these ores have relatively low iron contents, then the increased amount of nickel recovered at the higher nickel oxide contents resulted in significantly higher grades. 


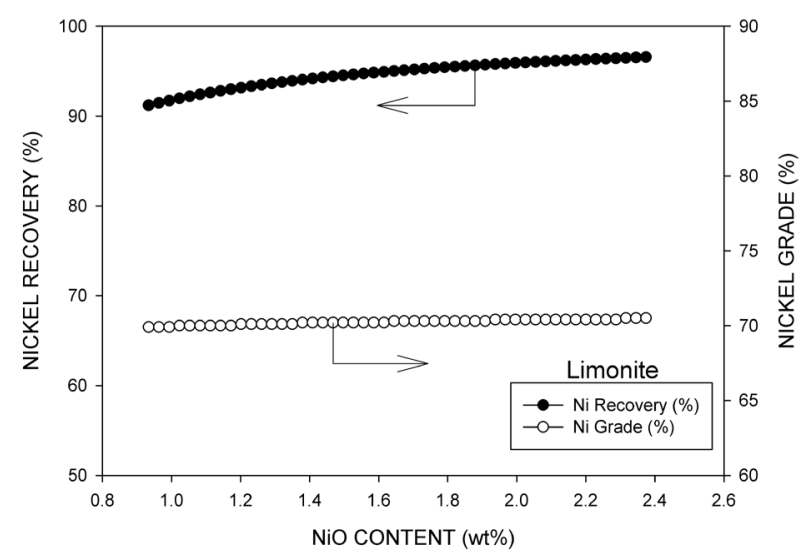

(a)

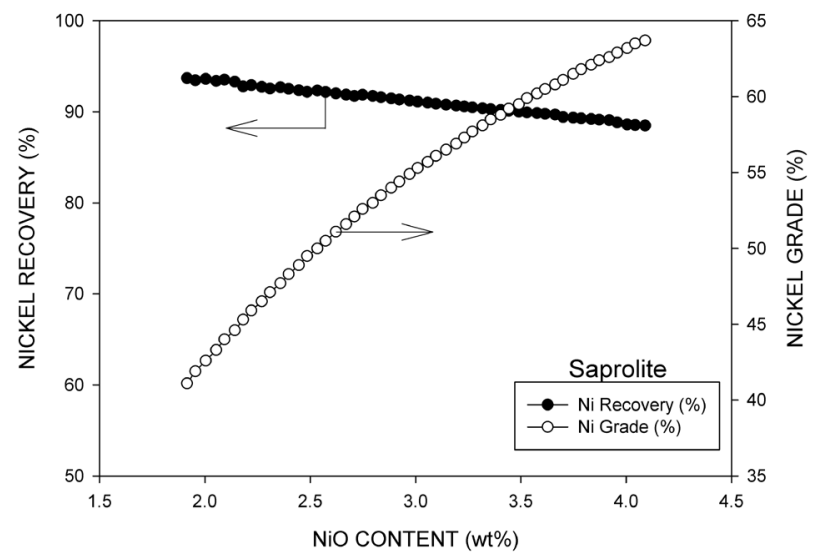

(b)

Figure 7. (a) Effect of nickel oxide content of the limonitic ore on the nickel recovery and the nickel grade of the ferronickel at $600^{\circ} \mathrm{C}$; (b) Effect of nickel oxide content of the saprolitic ore on the nickel recovery and the nickel grade of the ferronickel at $1150^{\circ} \mathrm{C}$.

Figure 8(a) and Figure 8(b) show the effect of the iron oxide content of the ore on the nickel recovery and grade for the limonitic and the saprolitic ores, respectively. For the saprolitic ore, the effect of increasing carbon is also included. The iron oxide content of the limonitic ore was decreased by increasing the silica content. For the limonitic ore, an increased amount of iron oxide resulted in an increased amount of metallic iron, which promoted increased nickel recovery via the lowering of the nickel activity in the ferronickel. However, this lowered the grade of the ferronickel. Conversely, for the saprolitic ore, where the carbon stoichiometric addition was much lower than for the limonitic ore, an increasing amount of iron oxide resulted in more oxidizing conditions and as a result more of the nickel oxide remained in the magnesium silicates. Consequently, the nickel recovery decreased dramatically, with increasing iron oxide but since the iron recovery decreased even more, then the grade increased. This oxidation effect can be negated by increasing the carbon addition. As the carbon content was increased, the nickel recovery could be maintained at high levels with increasing iron 
oxide. However, because of the increased reduction of iron oxide to metallic iron, the grade of the ferronickel decreased.

For the limonitic ore, changing the amount of silica lowered the amount of iron oxide and this has been discussed previously. Additionally, magnesia had very little effect. Figure 9(a) and Figure 9(b) show the effects of magnesia and silica, respectively, on the nickel recoveries and grades for the saprolitic ore. The addition of magnesium oxide resulted in slight decreases in nickel recovery and grade. For this particular ore composition with about $40 \%$ silica, increasing the magnesia content increased the amount of the magnesium silicates and thus the equilibrium amount of nickel oxide in the silicates increased, which lowered both the recovery and grade. Similarly, increasing the silica content of the ore lowered the nickel recovery. However, the grade increased since some of the silica reacts with iron to form iron silicates and this lowered the metallic iron recovery.

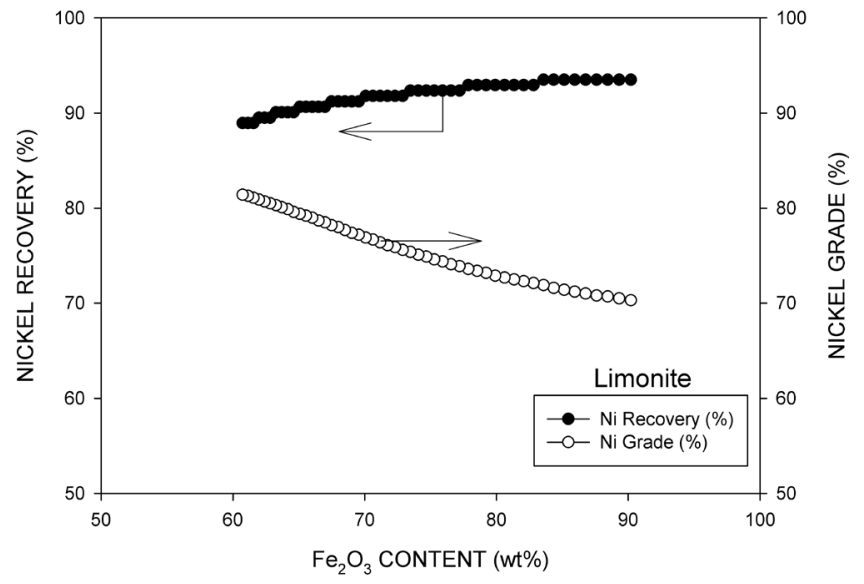

(a)

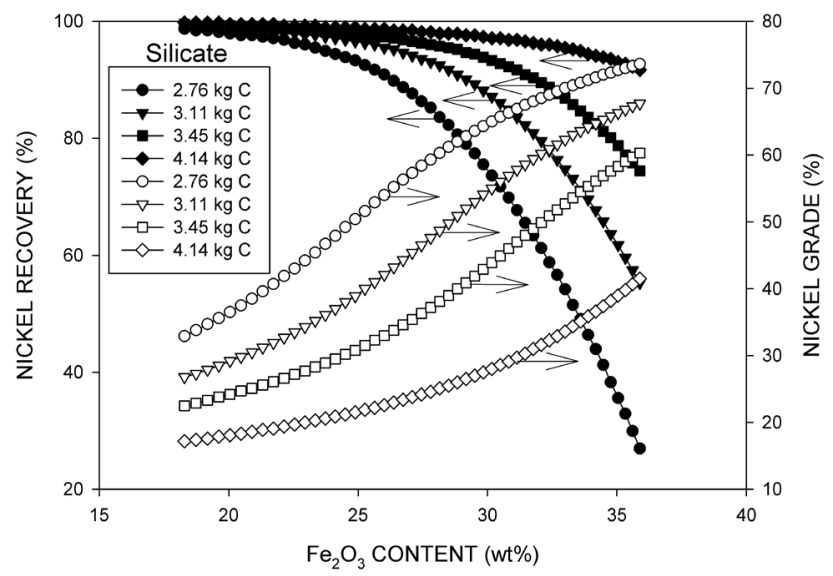

(b)

Figure 8. (a) Effect of iron oxide content of the limonitic ore on the nickel recovery and the nickel grade of the ferronickel at $600^{\circ} \mathrm{C}$; (b) Effect of iron oxide content of the saprolitic ore on the nickel recovery and the nickel grade of the ferronickel at $1150^{\circ} \mathrm{C}$. Also included is the effect of carbon additions. 


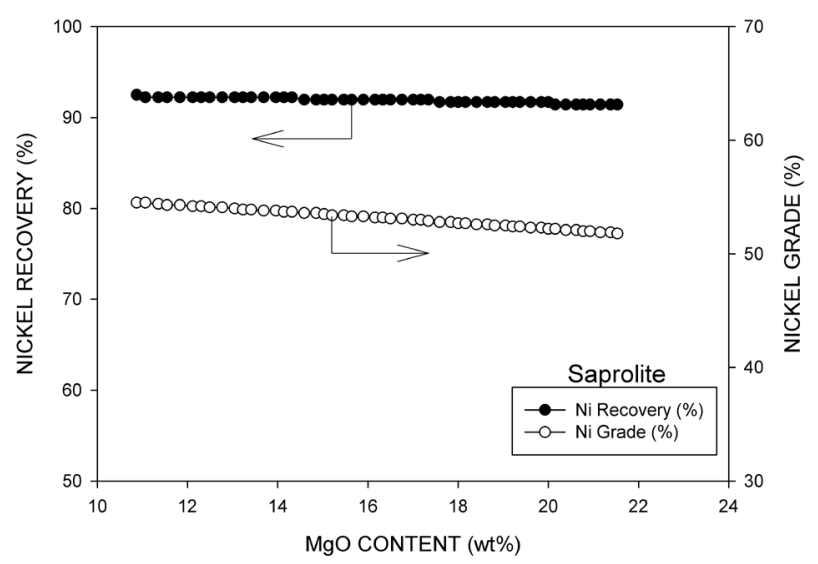

(a)

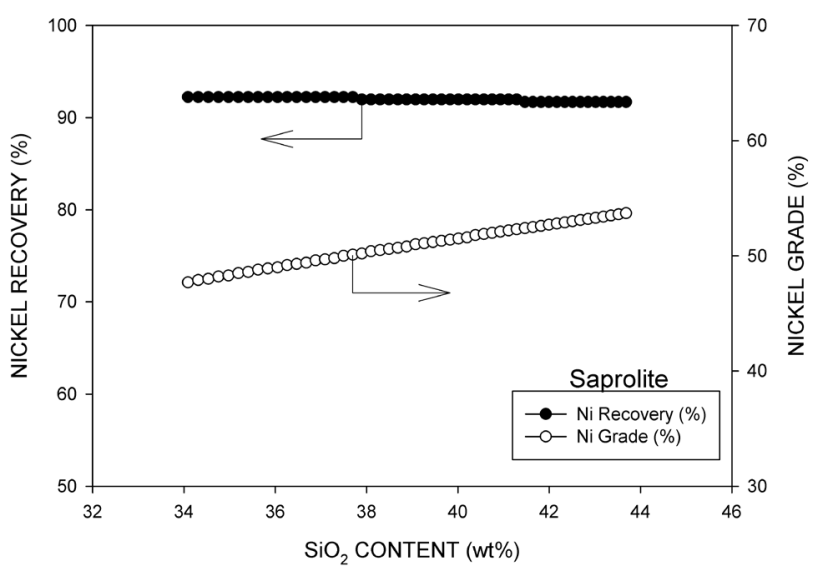

(b)

Figure 9. (a) Effect of magnesia (MgO) content of the saprolitic ore on the nickel recovery and the nickel grade of the ferronickel at $1150^{\circ} \mathrm{C}$; (b) Effect of silica $\left(\mathrm{SiO}_{2}\right)$ content of the saprolitic ore on the nickel recovery and the nickel grade of the ferronickel at $1150^{\circ} \mathrm{C}$.

Figure 10(a) and Figure 10(b) show the effect of carbon additions on the nickel recovery and the grade of the ferronickel for the limonitic and the saprolitic ores, respectively. For the current stoichiometric requirement of converting all of the nickel oxide to metallic nickel and all of the iron oxide to wüstite, the carbon additions as given previously were $7.07 \mathrm{~kg} / 100 \mathrm{~kg}$ of ore for the limonitic ore and $2.76 \mathrm{~kg} / 100 \mathrm{~kg}$ of ore for the saprolitic ore. For the limonitic ore it can be seen that the maximum nickel recovery of about $94 \%$ is achieved at a carbon addition of only about $2 \mathrm{~kg} / 100 \mathrm{~kg}$ of ore and the nickel grade is about $70 \%$. Above this carbon addition, the nickel recoveries and grades remained essentially constant. These results at $2 \mathrm{~kg} / 100 \mathrm{~kg}$ of ore would be satisfactory, but the requirement to convert the iron oxide to wüstite and minimize the amount of magnetite, necessitates an additional carbon addition of about $5 \mathrm{~kg} / 100 \mathrm{~kg}$ of ore, again reflecting the high iron oxide content of the limonitic ore. At the relatively low reduction temperature of $600^{\circ} \mathrm{C}$, additional carbon additions did not result in increased for 


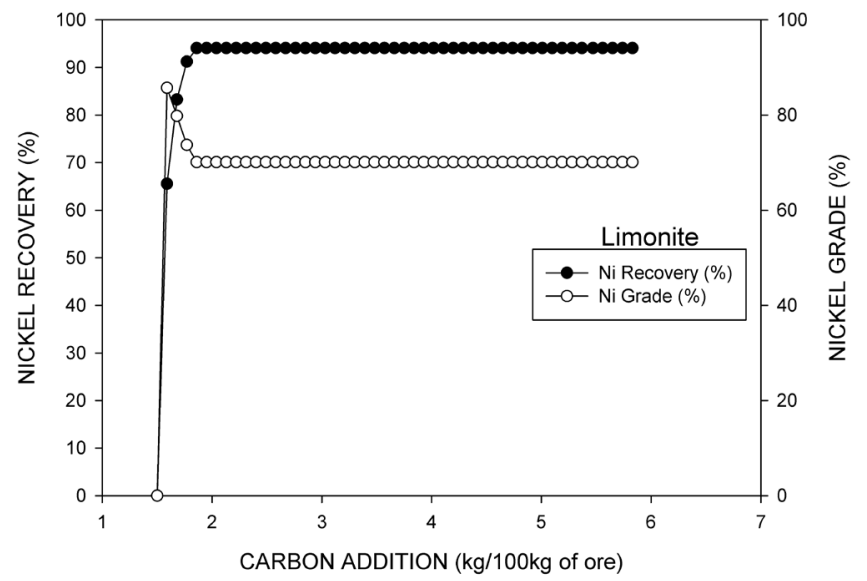

(a)

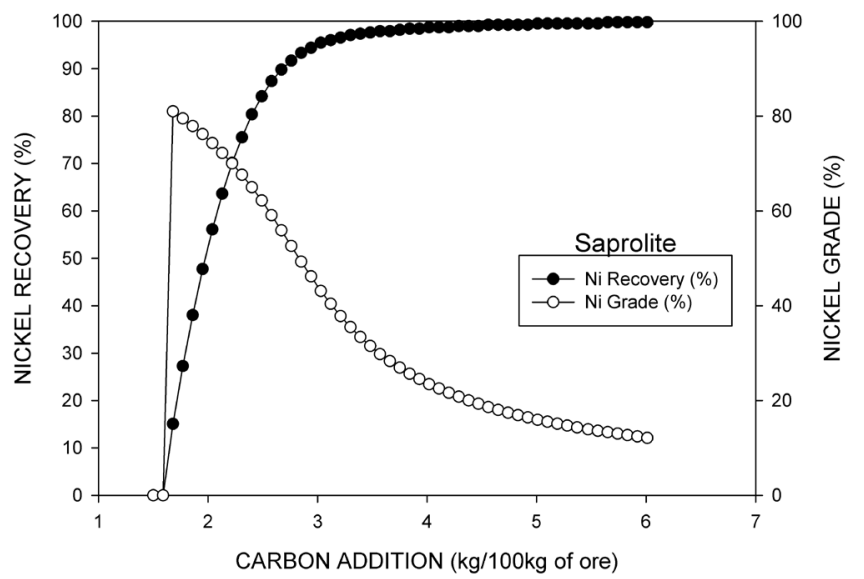

(b)

Figure 10. (a) Effect of carbon additions to the limonitic ore on the nickel recovery and the nickel grade of the ferronickel; (b) Effect of carbon additions to the saprolitic ore on the nickel recovery and the nickel grade of the ferronickel.

mation of metallic iron. For the saprolitic ore, the nickel recovery is high at the stoichiometric carbon requirement of $2.76 \mathrm{~kg} / 100 \mathrm{~kg}$ of ore and increases somewhat beyond this carbon addition before levelling off. Also the grade is high at $52 \%$, but decreased rapidly with increasing carbon addition due to the significant formation of additional metallic iron. For the saprolitic ore, the reduction temperature was $1150^{\circ} \mathrm{C}$ and reduction to metallic iron can occur more readily than for the limonitic ore at $600^{\circ} \mathrm{C}$.

\subsection{Comparison with Experimental Results}

There is a paucity of experimental information in the literature regarding the effect of the reduction temperature on the nickel recovery and grade for both ore types. Also there is considerable discrepancy with regards to the temperatures required to achieve the maximum nickel recovery for both the limonitic and the saprolitic ores. In some cases, an optimum temperature is reported beyond which the nickel recovery decreases. 
The experimental results available using either carbon, or $\mathrm{CO} / \mathrm{CO}_{2}$, or $\mathrm{H}_{2} / \mathrm{H}_{2} \mathrm{O}$ as reductants [29]-[32] are summarized in Table 3 and these can be compared to the thermodynamic predictions obtained in the present research, particularly those shown in Figure 3(a) and Figure 3(b). The ore type, the maximum recovery and the temperature of the maximum recovery are reported, as well as the nickel grade and whether an optimum was observed. It should be pointed out that in an actual reduction experiment, kinetic factors can play a significant role. Additionally, most experimental systems involve flowing gases and would be considered open, in contrast to the closed system employed in the thermodynamic model. Finally, it should be noted that when utilizing carbon as the reducing agent, the generated carbon monoxide plays a major role in the reduction process.

For both ore types, the nickel recovery should primarily be determined by the stability of the nickel oxide in the host mineral. The amount of iron also has an effect, as the activity of the nickel metal is lowered by the presence of metallic iron, which favors reduction. Despite the variation in the experimental reduction conditions and the ore compositions employed, several conclusions can be drawn. For the limonitic ores, it would be expected that the nickel oxide in the goethite would be relatively unstable. These ores also contain a significant amount of iron oxide and thus the reduction of the nickel oxide should be readily facilitated. The experimental results in Table 3 show that the limonitic ore is relatively easy to reduce and high nickel recoveries approaching one hundred percent can be readily achieved in the temperature range of $550^{\circ} \mathrm{C}$ to $700^{\circ} \mathrm{C}$. A slight optimum has been observed in some cases but high recoveries can be attained over a wide temperature range. This optimum is more likely to be observed with $\mathrm{CO} / \mathrm{CO}_{2}$ or $\mathrm{H}_{2} / \mathrm{H}_{2} \mathrm{O}$ gas mixtures than with carbon as the reducing agent. With the gas mixtures, reoxidation of some nickel can occur above the maximum and this can lead to a decrease in nickel recovery. On the other hand with carbon, the oxidation potential is generally lower than with the gaseous reductants and thus reoxidation may not be

Table 3. Summary of experimental results for prior reduction roasting studies of limonitic and saprolitic laterite ores. Maximum grade and recovery are given with key reduction conditions.

\begin{tabular}{|c|c|c|c|c|c|c|}
\hline Ore Type & Reductant & $\begin{array}{l}\text { Maximum Ni } \\
\text { Recovery (\%) }\end{array}$ & $\begin{array}{c}\text { Temp. of } \\
\text { Maximum Ni } \\
\text { Recovery }\left({ }^{\circ} \mathrm{C}\right)\end{array}$ & $\begin{array}{c}\text { Ni Grade At } \\
\text { Maximum (\%) }\end{array}$ & $\begin{array}{l}\text { Optimum } \\
\text { Observed }\end{array}$ & Reference \\
\hline Limonitic & $\mathrm{CO} / \mathrm{CO}_{2}$ & -100 & 550 & N/A & yes & [29] \\
\hline Limonitic & $\mathrm{H}_{2} / \mathrm{H}_{2} \mathrm{O}$ & -100 & 550 & N/A & N/A & [29] \\
\hline Limonitic & $\mathrm{CO}_{2} / \mathrm{H}_{2}$ & -100 & $700-800$ & 60 & yes & [30] \\
\hline Saprolitic & $\mathrm{CO} / \mathrm{CO}_{2}$ & 82 & 700 & N/A & yes & [29] \\
\hline Saprolitic & $\mathrm{CO} / \mathrm{CO}_{2}$ & 78 & 900 & N/A & yes & [29] \\
\hline Saprolitic & $\mathrm{H}_{2} / \mathrm{H}_{2} \mathrm{O}$ & 85 & 850 & N/A & N/A & [29] \\
\hline Saprolitic & $\mathrm{CO} / \mathrm{CO}_{2}$ & 85 & 740 & 41 & yes & [31] \\
\hline Saprolitic & $\mathrm{CO}$ & 75 & 800 & N/A & yes & [32] \\
\hline Saprolitic & C (anthracite) & 84 & 1000 & N/A & no & [32] \\
\hline
\end{tabular}


observed. Nickel grades up to $50 \%$ have been reported. These experimental results can be compared with the thermodynamic predictions shown in Figure 3(a). Here it can be seen that there is general agreement with the experimental results. In the present thermodynamic study, high nickel recoveries can be achieved over the temperature range of $550^{\circ} \mathrm{C}$ to $700^{\circ} \mathrm{C}$, with a maximum of about $99 \%$, being observed at about $700^{\circ} \mathrm{C}$. Grades in the range of 40 to $50 \%$ are achievable but at somewhat reduced recoveries. Above $700^{\circ} \mathrm{C}$, the grade drops dramatically due to the substantial reduction of the iron oxide to metallic iron. The thermodynamic and experimental results reflect the relative ease of reduction of the nickel oxide in the limonitic ores and the potential negative impact of the large amount of iron oxide in the ore on the nickel grade of the ferronickel. However, by careful control of the operating conditions it should be possible to achieve both high recoveries and high grades at relatively low temperatures, but the reaction kinetics may be slow.

The reduction behavior of the saprolitic ores is quite different from that of the limonitic ores, again reflecting the stability of the nickel oxide, in this case in the magnesium silicates. For the saprolitic ores, the experimental temperatures reported for maximum recovery for gaseous reduction, range from about $700^{\circ} \mathrm{C}$ to $900^{\circ} \mathrm{C}$ and therefore extend to a higher temperature than that for the limonitic ore. Also, the maximum recoveries are typically only about $80 \%$ in comparison to almost $100 \%$ for the limonitic ore. For the saprolitic ore, recoveries approaching $100 \%$ are only achieved under more strongly reducing conditions using solid carbon and temperatures up to about $1200^{\circ} \mathrm{C}$. These experimental results can be compared to the thermodynamic predictions as shown in Figure 3(b).

For the case of the saprolitic ores, it is likely that the nickel recovery is to a large extent a function of the amount of nickel oxide that exists in the pyroxene $\left(\mathrm{MgSiO}_{3}\right)$ and/or the olivine $\left(\mathrm{Mg}_{2} \mathrm{SiO}_{4}\right)$. Figure 11 shows the recoveries and grades, respectively, for the saprolite ore in which all the nickel oxide is present in either $\mathrm{MgSiO}_{3}$ or in $\mathrm{Mg}_{2} \mathrm{SiO}_{4}$. Also included is the data for an ore in which $50 \%$ of the nickel oxide is present in pyroxene and $50 \%$ in olivine. For the $\mathrm{NiO}$ in $\mathrm{MgSiO}_{3}$, reduction begins at the low temperature of about $330^{\circ} \mathrm{C}$ and proceeds rapidly with temperature, reflecting the relatively low stability of $\mathrm{NiO}$ in $\mathrm{MgSiO}_{3}$. At about $500^{\circ} \mathrm{C}$ the rate begins to slow down and recoveries approaching $95 \%$ can be realised even at $600^{\circ} \mathrm{C}$. At about $800^{\circ} \mathrm{C}$ a maximum recovery of about $99 \%$ can be achieved. Subsequently the recovery decreases as some nickel is reoxidized to $\mathrm{NiO}$ in the pyroxene. Thus, there is an optimum reduction temperature. On the other hand, the $\mathrm{NiO}$ in the olivine does not begin to reduce until about $800^{\circ} \mathrm{C}$, reflecting the much higher stability of $\mathrm{NiO}$ in $\mathrm{Mg}_{2} \mathrm{SiO}_{4}$. Thereafter, the reduction rate is rapid and within about $30^{\circ} \mathrm{C}$, about seventy percent of the nickel is recovered. Then, reduction proceeds very slowly and the recovery levels off at about $96 \%$ at $1300^{\circ} \mathrm{C}$. For the ore containing $50 \% \mathrm{NiO}$ in $\mathrm{MgSiO}_{3}$ and $50 \%$ in $\mathrm{Mg}_{2} \mathrm{SiO}_{4}$ an intermediate behavior is observed. The $\mathrm{NiO}$ in $\mathrm{MgSiO}_{3}$ is mainly reduced by about $800^{\circ} \mathrm{C}$ and this is rapidly followed by about $70 \%$ of the $\mathrm{NiO}$ in $\mathrm{Mg}_{2} \mathrm{SiO}_{4}$ giving an overall recovery of just over $80 \%$. However, to attain additional nickel recovery, much higher 
temperatures of up to $1200^{\circ} \mathrm{C}$ are needed and here the nickel recovery is about $95 \%$. Again some reoxidation of the $\mathrm{NiO}$ into the magnesium silicates is possible.

Figure 12 shows the temperature of the maximum nickel recovery and also the maximum nickel recovery as a function of the amount of $\mathrm{NiO}$ present in $\mathrm{MgSiO}_{3}$. Up to about $70 \% \mathrm{NiO}$ in $\mathrm{MgSiO}_{3}$, the amount of nickel recovered remained relatively constant at about $95 \%$, but the temperature of maximum recovery decreased from about $1300^{\circ} \mathrm{C}$ to $1150^{\circ} \mathrm{C}$. Beyond $70 \% \mathrm{NiO}$ in $\mathrm{MgSiO}_{3}$, there was a rapid decrease in the reduction temperature from about $1150^{\circ} \mathrm{C}$ to $750^{\circ} \mathrm{C}$ and the maximum recovery increased from about $95 \%$ to almost $100 \%$. Thus, depending on the relative amount of $\mathrm{NiO}$ present in either $\mathrm{MgSiO}_{3}$ or $\mathrm{Mg}_{2} \mathrm{SiO}_{4}$ the nickel recovery can change, but more dramatically, the temperature for maximum nickel recovery can vary over a wide range.

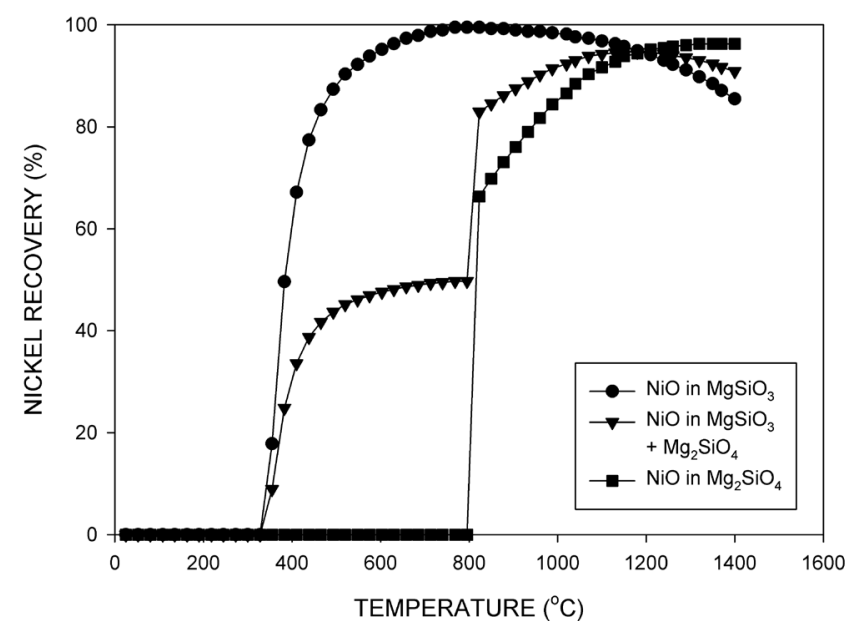

Figure 11. Nickel recovery as a function of temperature for $\mathrm{NiO}$ present in only $\mathrm{MgSiO}_{3}, \mathrm{NiO}$ present in only $\mathrm{Mg}_{2} \mathrm{SiO}_{4}$, and a blend of $\mathrm{NiO}$ in $\mathrm{MgSiO}_{3}$ plus $\mathrm{NiO}$ in $\mathrm{Mg}_{2} \mathrm{SiO}_{4}(50 / 50)$.

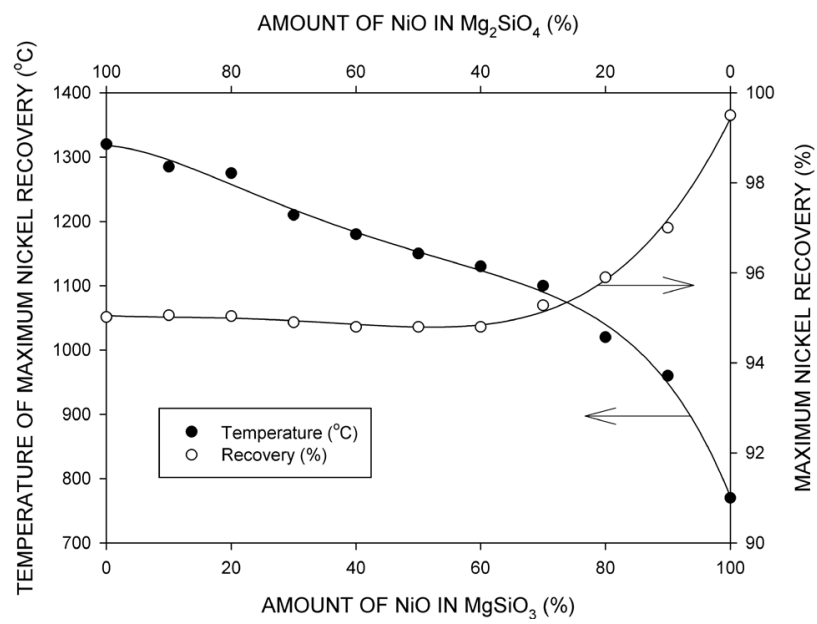

Figure 12. Temperature of maximum nickel recovery as a function of the amount of $\mathrm{NiO}$ in $\mathrm{MgSiO}_{3}$. Also included is the nickel recovery at that temperature. 
Figure 13 shows the nickel grades of the ferronickel for $\mathrm{NiO}$ in $\mathrm{MgSiO}_{3}$ and $\mathrm{NiO}$ in $\mathrm{Mg}_{2} \mathrm{SiO}_{4}$ and also for the $50 \% \mathrm{NiO}$ in $\mathrm{MgSiO}_{3}$ plus $50 \%$ in $\mathrm{Mg}_{2} \mathrm{SiO}_{4}$. For $\mathrm{NiO}$ in $\mathrm{MgSiO}_{3}$, the nickel grade is about $99 \%$ at about $350^{\circ} \mathrm{C}$, reflecting the relative ease of reduction of the $\mathrm{NiO}$ to metallic nickel in comparison to the more difficult reduction of the iron oxide to metallic iron. Thereafter, metallic iron is formed in increasing amounts and the grade drops to about $52 \%$ at about $800^{\circ} \mathrm{C}$ and then remains relatively constant. For the $\mathrm{NiO}$ in $\mathrm{Mg}_{2} \mathrm{SiO}_{4}$, the grade increases very rapidly beginning at $800^{\circ} \mathrm{C}$, reaching about $40 \% \mathrm{Ni}$ at $820^{\circ} \mathrm{C}$. Thereafter, the grade increases slowly to about $55 \% \mathrm{Ni}$ at $1400^{\circ} \mathrm{C}$. For the $50 / 50$ mixture, an intermediate behavior is observed. At $350^{\circ} \mathrm{C}$, the grade is about $50 \%$ but then drops as metallic iron forms. However, at about $800^{\circ} \mathrm{C}$ the $\mathrm{NiO}$ in $\mathrm{Mg}_{2} \mathrm{SiO}_{4}$ begins to be reduced and the grade increases from about $25 \%$ to about $55 \%$ at $1400^{\circ} \mathrm{C}$. Above about $800^{\circ} \mathrm{C}$, the grades for the three cases converge towards similar values in the range of about $53 \%$ to $57 \% \mathrm{Ni}$.

Thus, the thermodynamic results indicate that the reduction behavior of the saprolite ore depends to a large extent on the amount of $\mathrm{NiO}$ in $\mathrm{MgSiO}_{3}$ or $\mathrm{Mg}_{2} \mathrm{SiO}_{4}$. For example, a saprolitic ore with a large amount of $\mathrm{NiO}$ in $\mathrm{MgSiO}_{3}$ should have a high nickel recovery at relatively low temperatures. On the other hand, for an ore with a large amount of $\mathrm{NiO}$ in $\mathrm{Mg}_{2} \mathrm{SiO}_{4}$, about $70 \%$ to $80 \%$ of the nickel can be recovered by about $800^{\circ} \mathrm{C}$ but the recovery of the remaining nickel would entail more strongly reducing conditions and this would require carbon as a reductant and temperatures up to about $1200^{\circ} \mathrm{C}$. Since the iron oxide content of the ore is low then nickel grades of about $50 \%$ should be readily achievable. Thus, by partitioning the amount of $\mathrm{NiO}$ between pyroxene and olivine it is possible to obtain thermodynamic predictions for the saprolite ore, which are in general agreement with the experimental results presented in Table 3. In the case of the limonitic ores, the available nickel grades and recoveries are consistent with the model predictions for the given temperatures. In the case of the saprolitic ore,

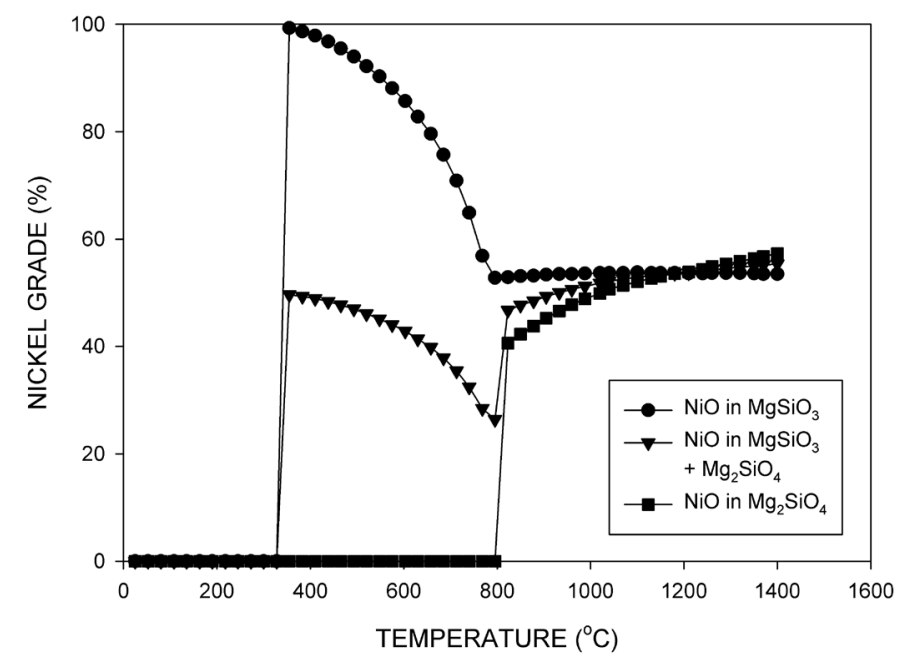

Figure 13. Nickel grade as a function of temperature for $\mathrm{NiO}$ present in only $\mathrm{MgSiO}_{3}, \mathrm{NiO}$ present in only $\mathrm{Mg}_{2} \mathrm{SiO}_{4}$ and a $\mathrm{NiO}$ present in both $\mathrm{MgSiO}_{3}$ and $\mathrm{Mg}_{2} \mathrm{SiO}_{4}(50 / 50)$. 
two of the reported temperatures are slightly $\left(100^{\circ} \mathrm{C}-150^{\circ} \mathrm{C}\right)$ lower than the model predictions, but otherwise the experimental results are comparable to the model output.

\section{Conclusions}

A thermodynamic model has been used to compare the reduction behaviours of a limonitic ore with a saprolitic ore. The carbon requirement was determined as that required to reduce all of the nickel oxide to nickel metal and all of the iron oxide to wüstite $(\mathrm{FeO})$. There is a strong thermodynamic justification for the selective reduction and extraction of nickel from the nickeliferous laterite ores, and moderate reductant additions are predicted to yield nickel recoveries in excess of $90 \%$ and nickel grades up to $50 \%$, depending on the composition of the ore and the reduction environment employed.

Different optimal reduction conditions have been identified for the limonitic and the saprolitic ores. For the limonitic ore, for reduction temperatures of about $650^{\circ} \mathrm{C}$, the nickel recovery was about $95 \%$ and the nickel grade was about $50 \%$. Below $700^{\circ} \mathrm{C}$, the grade decreased with increasing recovery. At temperatures approaching $700^{\circ} \mathrm{C}$ and above, the nickel recoveries remained close to $100 \%$ but the grade dropped to about $5 \%$. These relatively low reduction temperatures reflect the low stability of the nickel oxide in goethite. Thermodynamically, the reduction of the limonitic laterite can be satisfactorily achieved at temperatures below $700^{\circ} \mathrm{C}$, but for kinetic reasons higher temperatures may be required. For the saprolite ore, in which the nickel oxide is dissolved in the magnesium silicates, much higher operating temperatures are required. Nickel recoveries of only about $65 \%$ can be achieved by $825^{\circ} \mathrm{C}$. To achieve recoveries of about $95 \%$, temperatures approaching $1100^{\circ} \mathrm{C}$ are required and here the nickel grade is about $50 \%$.

The thermodynamic model shows that for the saprolites, the temperature for maximum nickel recovery depends on the amount of $\mathrm{NiO}$ in either $\mathrm{MgSiO}_{3}$ or $\mathrm{Mg}_{2} \mathrm{SiO}_{4}$. Nickel oxide in $\mathrm{MgSiO}_{3}$ is relatively unstable and nickel recoveries of over $95 \%$ can be achieved at about $900^{\circ} \mathrm{C}$. However, the $\mathrm{NiO}$ in $\mathrm{Mg}_{2} \mathrm{SiO}_{4}$ is much more stable and although about $70 \%$ of the nickel can be recovered at $800^{\circ} \mathrm{C}$, much higher temperatures of $1200^{\circ} \mathrm{C}$ to $1300^{\circ} \mathrm{C}$ are required to attain recoveries approaching $95 \%$. For ores containing some $\mathrm{NiO}$ in $\mathrm{MgSiO}_{3}$ and some in $\mathrm{Mg}_{2} \mathrm{SiO}_{4}$ an intermediate behavior would be expected.

A 50/50 blend of the two ores has also been examined and the optimal temperature for the reduction of this ore was identified as about $850^{\circ} \mathrm{C}$. A nickel recovery of $94 \%$ with a nickel grade of $18 \%$ is predicted for the blended ore at this temperature. The recoveries and grades for the blended ore are intermediate between those of the limonitic and saprolitic ores. In the blended ore, the two ores are reduced sequentially, with the nickel oxide from the limonitic portion of the blended ore being reduced first at lower temperatures and then the nickel oxide from the saprolitic portion of the ore is reduced at higher temperatures. However, the presence of the iron oxide and hence the metallic iron from the limonitic ore, lowers the reduction temperature and improves the nickel recovery from the saprolitic portion. On the other hand, the presence of this additional 
iron lowers the grade of the ferronickel in comparison to that from the saprolitic ore alone.

With regards to ore composition, increasing nickel oxide content had only a minor effect on the nickel recovery and grade for the limonitic ore. However, for the saprolitic ore, the recovery decreased and the grade increased with increasing nickel oxide. For the limonitic ore, an increasing amount of iron oxide lowered the grade but increased the recovery, while for the saprolitic ore the opposite behavior was observed. The saprolitic ore was much more sensitive to the amount of iron oxide as the conditions became more oxidizing with increasing iron oxide. This could be countered by increasing the amount of carbon. For the saprolitic ore, increasing the amount of magnesia lowered the recovery and grade, while increasing silica lowered the recovery but increased the grade.

The optimal reduction conditions identified for both ores by thermodynamic modelling are generally supported by the experimental findings in the literature. The behavior of the nickel oxide is mainly determined by its stability in the host mineral. For the limonitic ore, both the thermodynamic model and the experimental results indicate that recoveries approaching $100 \%$ can be achieved in the temperature range from about $550^{\circ} \mathrm{C}$ to $700^{\circ} \mathrm{C}$. Here the thermodynamic model and some limited experimental information indicate that grades of over $50 \%$ are feasible. However, because of the slow kinetics expected at these temperatures it may be necessary to operate at higher temperatures. Since there is considerable iron oxide in the limonitic ore and significant production of metallic iron would be expected at these higher temperatures, then the nickel grade could rapidly decrease to values as low as $5 \%$. For the saprolitic ore, the experimental temperature range for reduction is higher, from $700^{\circ} \mathrm{C}$ to $900^{\circ} \mathrm{C}$, and here the nickel recovery is only about $80 \%$. From a thermodynamic perspective, about $65 \%$ of the nickel can be recovered at $825^{\circ} \mathrm{C}$ and thereafter the recovery increases slowly to about $90 \%$ at about $1150^{\circ} \mathrm{C}$. By considering that the $\mathrm{NiO}$ in the saprolitic ore is partitioned between both $\mathrm{MgSiO}_{3}$ and $\mathrm{Mg}_{2} \mathrm{SiO}_{4}$, then the thermodynamic predictions can be adjusted to more closely match the experimental findings with about $80 \%$ of the nickel being recovered at $800^{\circ} \mathrm{C}$. Because of the high stability of the remaining nickel oxide, the recovery increases very slowly with increasing temperature, with recoveries of about $95 \%$ at $1200^{\circ} \mathrm{C}$. For the saprolitic ore, the amount of nickel oxide is higher and the amount of iron oxide is lower than for the limonitic ore and thus nickel grades in the range of about $40 \%$ to $50 \%$ should be achievable.

\section{Acknowledgements}

The authors thank the Natural Sciences and Engineering Research Council of Canada (NSERC) for support of this research.

\section{References}

[1] US Geological Survey (2016) Nickel. Mineral Commodity Summaries, 114-115.

[2] Foose, M.P. (1991) Nickel-Mineralogy and Chemical Composition of Some Nickel-Bear- 
ing Laterites in Southern Oregon and Northern California. 1-24.

[3] Manceau, A. and Calas, G. (1986) Nickel-Bearing Clay Minerals II. Intracrystalline Distribution of Nickel: An X-Ray Absoprtion Study. Clay Minerals, 21, 341-360.

http://dx.doi.org/10.1180/claymin.1986.021.3.07

[4] Whittington, B.I. and Muir, D. (2000) Pressure Acid Leaching of Nickel Laterites: A Review. Mineral Processing and Extractive Metallurgy Review, 21, 527-599. http://dx.doi.org/10.1080/08827500008914177

[5] Harris, C., Peacey, J. and Pickles, C.A. (2009) The Thermal Upgrading of Nickeliferous Lateritic Ores-A Review. Proceedings of the 48 th Conference of Metallurgists, Sudbury, 23-26 August 2009, 51-75.

[6] Rao, M., Li, G., Jiang, T., Luo, J., Zhang, Y. and Fan, X. (2013) Carbothermic Reduction of Nickeliferous Laterite Ores for Nickel Pig Iron Production in China: A Review. JOM, 65, 1573-1583. http://dx.doi.org/10.1007/s11837-013-0760-7

[7] Canterford, B.J.H. and Turnbull, A.G. (1980) The Reduction of Nickeliferous Laterites: Thermodynamic Considerations. Proceedings of the Australasian Institute of Mining and Metallurgy, Sydney, July 1980, 43-51.

[8] Jivasek, J. and Pedlik, J. (1990) Thermodynamic Study on the Reduction of Nickel-Ferrous Laterites. Hutnicke Listy, 45, 128-131.

[9] Utigard, T. and Bergman, R.A. (1992) Gaseous Reduction of Laterite Ores. Metallurgical Transactions B, 24, 271-275. http://dx.doi.org/10.1007/BF02659129

[10] Valix, M., Cheung, W.H., Dan, P.D. and Foulds, G.A. (1995) Thermodynamic Analysis of the Reduction of Nickel Laterite Ores. 23rd Australasian Conference on Chemical Engineering, Institution of Engineers, Adelaide, 24-27 September 1995, 142-146.

[11] Hallet, C.J. (1997) A Thermodynamic Analysis of the Solid State Reduction of Nickel from Laterite Minerals. Proceedings of Nickel-Cobalt 97 International Symposium Pyrometallurgical Fundamentals and Process Development, Sudbury, 17-20 August 1997, 299-312.

[12] Li, S. (1999) Study of Nickeliferrous Laterite Reduction. Masters Thesis (M.A.Sc.) Thesis, Mcmaster University, Hamilton.

[13] Rhamdhani, M.A., Hayes, P.C. and Jak, E. (2009) Nickel Laterite Part 2-Thermodynamic Analysis of Phase Transformations Occurring during Reduction Roasting. Mineral Processing and Extractive Metallurgy, 118, 146-155. http://dx.doi.org/10.1179/174328509X431409

[14] Pickles, C.A., Forster, J. and Elliott, R. (2014) Thermodynamic Analysis of the Carbothermic Reduction Roasting of a Nickeliferous Limonitic Laterite Ore. Minerals Engineering, 65, 33-40. http://dx.doi.org/10.1016/j.mineng.2014.05.006

[15] Swinbourne, D.R. (2014) Understanding Ferronickel Smelting from Laterites through Computational Thermodynamics Modelling. Mineral Processing and Extractive Metallurgy, 123, 127-140. http://dx.doi.org/10.1179/1743285514Y.0000000056

[16] Pickles, C.A. and Elliott, R. (2015) Thermodynamic Analysis of Selective Reduction of Nickeliferous Limonitic Laterite Ore by Carbon Monoxide. Mineral Processing and Extractive Metallurgy, 124, 208-216. http://dx.doi.org/10.1179/1743285515Y.0000000009

[17] Diaz, C.D., Garces, A., Restrepo, O.J., Lara, M. and Camporredondo, J.E. (2015) Thermodynamic Analysis of the Reduction Process of Columbian Lateritic Nickel Ore. Revista de Metalurgia, 51, e057. http://dx.doi.org/10.3989/revmetalm.057

[18] Landers, M., Gräfe, M., Gilkes, R.J., Saunders, M. and Wells, M.A. (2011) Nickel Distribution and Speciation in Rapidly Dehydroxylated Goethite in Oxide-Type Lateritic Nickel Ores: XAS and TEM Spectroscopic (EELS and EFTEM) Investigation. Australian Journal of 
Earth Sciences, 58, 745-765. http://dx.doi.org/10.1080/08120099.2011.602985

[19] Valix, M. and Cheung, W.H. (2002) Study of Phase Transformation of Laterite Ores at High Temperature. Minerals Engineering, 15, 607-612. http://dx.doi.org/10.1016/S0892-6875(02)00068-7

[20] Bunjaku, A., Kekkonen, M. and Holappa, L. (2010) Phenomena in Thermal Treatment of Lateritic Nickel Ores up to $1300^{\circ}$ C. 12 th International Ferroalloys Congress, Helsinki, 6-9 June 2010, 641-652.

[21] Bunjaku, A., Kekkonen, M., Taskinen, P. and Holappa, L. (2011) Thermal Behaviour of Hydrous Nickel-Magnesium Silicates When Heating up to $750^{\circ} \mathrm{C}$. Mineral Processing and Extractive Metallurgy, 120, 139-146. http://dx.doi.org/10.1179/1743285511Y.0000000011

[22] Ball, M.C. and Taylor, H.F.W. (1963) The Dehydration of Chrysotile in Air and under Hydrothermal Conditions. Mineralogical Magazine, 33, 467-482. http://dx.doi.org/10.1180/minmag.1963.033.261.04

[23] Elliott, R., Rodrigues, F., Pickles, C.A. and Peacey, J. (2015) A Two Stage Thermal Upgrading Process for Nickeliferous Limonitic Laterite Ores. Canadian Metallurgical Quarterly, 54, 395-405. http://dx.doi.org/10.1179/1879139515Y.0000000009

[24] Liu, M., Lv, X., Guo, E., Chen, P. and Yuan, Q. (2014) Novel Process of Ferronickel Nugget Production from Nickel Laterite by Semi-Molten State Reduction. ISIJ International, 54, 1749-1754. http://dx.doi.org/10.2355/isijinternational.54.1749

[25] Pelton, A.D., Schmalzried, H. and Sticher, J. (1979) Computer-Assisted Analysis and Calculation of Phase Diagrams of the Fe-Cr-O, Fe-Ni-O and $\mathrm{Cr}-\mathrm{Ni}-\mathrm{O}$ Systems. Journal of Physics and Chemistry of Solids, 40, 1103-1122. http://dx.doi.org/10.1016/0022-3697(79)90146-X

[26] Hsieh, K.-C. and Chang, Y.A. (1986) A Solid-State Emf Study of Ternary Ni-S-O, Fe-S-O, and Quaternary Fe-Ni-S-O. Metallurgical Transactions B, 17, 133-146. http://dx.doi.org/10.1007/BF02670826

[27] Swartzendruber, L.J., Itkin, V.P. and Alcock, C.B. (1991) The Fe-Ni (Iron-Nickel) System. Journal of Phase Equilibria, 12, 288-312. http://dx.doi.org/10.1007/BF02649918

[28] Shirane, Y., Nabika, S., Sakamoto, S. and Nakashima, I. (1987) Activity Measurements in the Oxide Solid Solutions of $\mathrm{NiO}-\mathrm{MgO}$ and $\mathrm{NiO}-\mathrm{MgO}-\mathrm{SiO}_{2}$ Systems in the Temperature Range Between 1073 and 1273 K. International Journal of Mineral Processing, 19, 237-251. http://dx.doi.org/10.1016/0301-7516(87)90044-5

[29] De Graaf, J.E. (1979) The Treatment of Lateritic Nickel Ores-A Further Study of the Caron Process and Other Possible Improvements. Hydrometallurgy, 5, 47-65. http://dx.doi.org/10.1016/0304-386X(79)90027-6

[30] Chen, S., Guo, S., Xu, Y., Jiang, L. and Ding, W. (2014) Research on Selective Reduction of Laterite Nickel Ore by $\mathrm{CO}_{2} / \mathrm{H}_{2}$ Mixed Gas. Advanced Materials Research, 1025-1026, 814819.

[31] Yang, J., Zhang, G., Jahanshahi, S. and Ostrovski, O. (2015) Reduction of a Garnieritic Laterite ore by $\mathrm{CO}-\mathrm{CO}_{2}$ Gas Mixtures. Proceedings of the 14th International Ferroalloys Congress, Ukraine, 31 May-4 June 2015, 518-527.

[32] Li, B., Wang, H. and Yonggai, W. (2011) The Reduction of Nickel from Low-Grade Nickel Laterite Ore Using a Solid-State Deoxidisation Method. Minerals Engineering, 24, 15561562. http://dx.doi.org/10.1016/j.mineng.2011.08.006 
Submit or recommend next manuscript to SCIRP and we will provide best service for you:

Accepting pre-submission inquiries through Email, Facebook, LinkedIn, Twitter, etc. A wide selection of journals (inclusive of 9 subjects, more than 200 journals)

Providing 24-hour high-quality service

User-friendly online submission system

Fair and swift peer-review system

Efficient typesetting and proofreading procedure

Display of the result of downloads and visits, as well as the number of cited articles

Maximum dissemination of your research work

Submit your manuscript at: http://papersubmission.scirp.org/

Or contact jmmce@scirp.org 